\title{
Beş Vakit'in Sonsuz Zamanlarının Heterotopyalarında Gezinen Çocuklar
}

\author{
B. Gülçin ÖZDEMiR
}

doktor

glcnzdmr.777@gmail.com

\section{Abstract \\ Children Walking Through the Heterotopias of the Endless Time of Five Time and Winds}

Space and time in film narrative represent the relationships between characters and narrative and allow developing the relation between the narrative and the character. Relations between characters and space have a vital role to understand the space with regard to spectators. In this case, time concept contributes in explaining the meaning of space element, which is an important element in the narrative. In this study, main characters of Reha Erdem's film Beş Vakit, Yakup, Ömer and Yıldız's lifes in the village are discussed as the basis of space element through the heterotopia concept of Henri Lefebvre. Village is a space in the focus of the narrative and the time spent in the village also shapes the lives of the characters in that respect. In this context, based on the relationship of the characters with the narrative, time element in the narrative is interpreted through the chronotope concept proposed by Mikhail Bakhtin. Theoretical framework of the represented narrative space is constituted by Michael Foucault's heterotopia concept and Edward Soja's third space discussions. Analyzing space and time concepts in the focus of the narrative in terms of their relationships with characters with heterotopia 
and chronotope concepts on the basis of narratology also enables the spectators question the film's inference.

keywords: time and winds, space, time, heterotopia, choronotope

\section{Résumé}

\section{Les Enfants Qui se Promènent dans Les Hétérotopies du Temps Infini du Film des Temps et des Vents}

La temporalité et l'espace narratifs du film permettent au spectateur de comprendre et de développer le lien tissé entre les personnages et le récit. Les relations que ces derniers établissent avec l'espace jouent un rôle déterminant dans la conception de l'environnement narratif aux yeux du spectateur. L'élément du temps, en plus d'être l'un des éléments les plus importants du récit, contribue aussi à la conception de l'espace narratif. Ce travail analyse la vie des personnages principaux du film de Reha Erdem, Beş Vakit (Cinq Fois)Jacob, Ömer et Yıldız- en se basant sur un concept narratologique de l'espace basé sur l'hétérotopie discutée par Henri Lefebvre. Le village est un espace qui se trouve au centre du récit et le temps passé dans ce village façonne aussi de ce point de vue la vie des personnages. Dans ce contexte, la relation de l'élément du temps du récit avec les personnages a été examinée sur la base du concept de chronotope interprété par Mikhail Bakhtin. Le cadre théorique de la présentation de l'espace narratif est composé du concept d'hétérotopie de Michel Foucault et des discussions du troisième espace d'Edward Soja. En ce qui concerne la méthode de la narratologie, les éléments du temps et de l'espace sont les facteurs qui accentuent l'aspect dramatique du récit. L'analyse des concepts d'espaces et de temps au centre de la narration vis à vis de la relation de leurs personnages avec les concepts d'hétérotopie et de chronotope en tant que base de la narratologie permet aussi aux spectateurs de remettre en question l'inférence de l'œuvre.

mots-clés: des Temps et des Vents, espace, temps, hétérotopie, chronotope 
Öz

Film anlatısında mekân ve zaman, karakterlerin anlatılla kurduğu ilişkiyi izleyiciye sunmakta ve öyküyle karakter ilişkisinin gelişmesine olanak sağlamaktadır. Karakterlerin mekânla kurdukları ilişkiler, mekânın izleyiciaçısından anlamlandırılmasında önemli rol oynamaktadır. Zaman öğesi ise, anlatının önemli öğelerinden biri olmakla birlikte mekân öğesinin anlamlandırılmasına da katkı sağlamaktadır. Çalışma, Reha Erdem'in Beş Vakit filmindeki baş karakterler; Yakup, Ömer ve Yıldız adlı çocukların köydeki hayatlarını anlatıbilimin öğelerinden mekân öğesi temelinde Henri Lefebvre'nin tartıştığı heterotopya kavramıyla incelemiştir. Köy, anlatıda odak merkezde bulunan bir mekândır ve köyde yaşanılan zaman da bu minvalde karakterlerin yaşamlarını şekillendirmektedir. Bu bağlamda, karakterlerin anlatıyla olan ilişkisi temelinde anlatıdaki zaman öğesi de Mikhail Bakhtin'in yorumladığı kronotop kavramıyla incelenmiştir. Anlatı mekanının sunumunun teorik çerçevesi ise Michael Foucault'nun heterotopya kavramı ve Edward Soja'nın üçüncü mekan tartışmalarıyla oluşturulmuştur. Anlatının odak merkezindeki mekân ve zaman öğelerinin karakterlerle ilişkilerinin anlatıbilim temelinde; heterotopya ve kronotop kavramlarıla incelenmesi, filmin anlatım dilinin izleyiciler açısından sorgulanışını da sağlamaktadır.

anahtar kelimeler: beş vakit, mekân, zaman, heterotopya, kronotop 


\section{Giriş}

Vakitsiz salınan yaprakların iz düşümleri arasında hayat, Ta ki biz gerçekliği bulana dek, Verilenle yetineniz.... (Özdemir, 2016)

David Bordwell'a göre, anlatının uzun bir tarihçesi vardır ve 20. yüzyılda kavramın temel sorgulamaları yapılmaya başlanmıştır. Anlatı kavramı daha sonra, anlatıbilim olarak kullanılmaya başlanmış ve bu kullanımdan da vazgeçilmemiştir (Bordwell, 2017, s. 1). Anlatıbilim, film anlatılarında; zamanın, mekânın, karakterlerin, olay örgüsünün, olaylar arasındaki neden-sonuç ilişkilerinin ve anlatıcı kavramlarının incelenmesini sağlamaktadır. Anlatılar incelenirken, zaman, mekân ve karakterler hem anlatıcının bakış açısından hem de izleyicinin bakış açısından da değerlendirilebilmektedir. Bordwell, film anlatısı içindeki mekânların analiz edilmesinde, öykü mekânının, olay örgüsü mekânının ve sinema ekranı mekânının yani çerçeve içindeki görülebilir mekânın incelendiğini belirtmektedir (Bordwell, 2012, s. 90). Olay örgüsü, filmde görülebilir, duyulabilir her şeyi tanımlamak için kullanılırken, öykü kavramı ise, bazı diegetik olayları ima ederek, olay örgüsünün ötesine geçen bir kavram olmaktadır (Bordwell, 2012, s. 8081). Ekran mekânı ise, renklerin ve biçimlerin düz bir düzenini sunan mekândır (Bordwell, 2012, s. 148). Bu sinematografik kavramlar doğrultusunda, olay örgüsü mekânı, öykünün geçtiği mekânları izleyiciye sunmaktadır; öykü mekânı, olay örgüsü mekânında sunulan mekânlardan daha geniş perspektifli düşünme süreçlerine izin veren mekânları da sunarken ekran mekânı, sabit çerçeve içinde görünen mizanseni izleyiciye sunan mekân olmaktadır. Dolayısıyla izleyici sabit çerçeve içinde izlediği sahnelerle, olay örgüsünün geçtiği mekânları da algılayarak öyküyle birlikte izleyicinin zihninde tahayyüllere imkân veren öykü mekânlarını soyut şekilde algılayabilmekte ve anlamlandırabilmektedir. Bordwell, film anlatılarında ampirik olarak var olmayan soyut mekânların da olabileceğini söyler ve Sovyet Sineması'nın soyut mekânları kullandığını belirtir. Anlatıda boşluk bırakılan kısımların izleyici tarafından tamamlanmasıyla soyut mekânların anlaşılabileceğini söyleyen Bordwell, zamanın ve mekânın eksik parçalarının izleyicinin bilişsel zorlamasıyla tamamlanabileceğini ifade etmektedir (Bordwell, 1985, s. 243-244). Bu bağlamda, olay örgüsü mekânlarında gösterilmeyen mekânlar, izleyicinin tahayyülleri doğrultusunda zihinlerinde oluşturdukları soyut mekânlarla film anlatısını izlemelerini sağlar. Çağdaş anlatı sineması, izleyicinin düşünmesini ve anlatıyla birlikte ortaya çıkan soruların sorgulanmasını sağladığı için soyut mekânların kullanımını olanaklı kılmaktadır. Mieke Bal, Anlatıya Giriş Anlatının Teorisi (1985) adlı kitabında, mekânın hikâyedeki temsilinin önemine değinerek görmenin, duymanın ve dokunmanın algısal olarak mekân temsilinin içeriğinde bulunduğunu belirtmiştir. Mekânın karakterlerle bağlantılı olması, yaşayanların mekâna duygularını aktarmasını da sağlamaktadır (Bal, 1999, s. 133). Zaman da mekân kadar anlatıda rol oynamaktadır. Seymour Chatman'a göre, zaman, mekânla birlikte anlatının ruh haline katkıda bulunmaktadır (Chatman, 2009, s.132). Film anlatısında mekân ve zaman kavramlarının 
karakterlerle ilişkileri film kuramcıları tarafından önem arz etmektedir. Chatman, zaman ve mekânın, olay örgüsü ve karakterlerle ilişkili olarak sınıflandırılması gerektiğini önermiştir (Chatman, 2009, s. 133). Mekânların izleyici tarafından algılanması ve anlamlandııımasında yönetmenin mekânları temsil ediş biçimi de bu bağlamda ön plana çıkmaktadır. Karakterlerin mekânlarla kurdukları ilişkiler, içsel çatışmalarına dair işaretlerin mekânlarla bağlantısı, izleyicinin filmi izleme deneyimine etki etmektedir. Anlatının öğelerinden mekân ve zaman kavramları üzerine düşünen teorisyenler, film anlatılarında zamanın ve mekânın kullanım stratejilerine de katkılarda bulunmaktadırlar. Mekân kavramının, bazı teorisyenlerce uzam, bazı teorisyenlerce yer olarak kullanılageldiği görülmüştür, ancak çalışmada mekân kavramının kullanımı film incelemesi açısından uygun görülmüştür. Mekânın sinema anlatısındaki anlamı, kavramın çalışmada kullanılma nedenini oluşturmaktadır. Sosyoloji alanında çalışan, 21.yüzyıın önde gelen teorisyenlerinden Michael Foucault'nun kavramsallaştırmaları da sinema anlatıları açısından tartışılabilir niteliktedir. Filoloji eğitimi görmüş Mikhail Bakhtin ise, edebi anlatılarda zaman ve mekân üzerine çalışarak akademik yazında metinlerarası ilişkilerle ilgili felsefi düşünceler geliştirilmesini olanaklı kılmıştır. Çalışmada anlatıda sunulan mekânlar, Michael Foucault'nun heterotopya kavramına getirdiği yorumlar ışığında ve Mikhail Bakhtin'in kronotop (zamanmekân) kavramına dair sorguladığı düşünceler çerçevesinde incelenmiştir. Bu bağlamda çalışmanın temelini oluşturan kavramlar doğrultusunda izleyicinin, anlatıdaki mekân ve zaman kavramını anlamlandırma süreciyle ilgili çoklu perspektiflerden çıkarımlar yapmaları sağlanmaktadır. Heterotopya kavramıyla birlikte değerlendirilen Henri Lefevbre'nin nitelendirdiği yaşanan mekânlar ve Edward Soja'nın yorumladığı üçüncü mekân gibi kavramlar da film incelemelerinde yer verilmiş ve böylece filmin anlatıbilim temelinde çoklu okumasının yapılması olanaklı kılınmıştır. Mekânlarla ilgili analizlerde, anlatı mekânlarının içeriği soyut kavramlarla analiz edilerek mekânların sinematik açıdan biçimsel sunumlarına da değinilmiştir. Anlatı mekânlarının haritalanmasını açıklayan James E. Cutting, Catalina Iricinschi, and Kaitlin L. Brunick'in Miss Yujin'den aktardıklarına göre de anlatı mekânları sadece fiziksel olmak durumunda değillerdir, duygusal ve psikolojik de olabilirler. Çoğu film de soyut anlatı mekânlarıyla bir atmosfer ve hava yaratabilmektedir (Cutting vd., 2013, s. 64). Bu bağlamda, film incelemesinde kullanılan kavramların içeriği hakkında bilgiler verilerek kavramlarla ilgili düşünürlerin ve teorisyenlerin yorumlarına yer verilmiş ve anlatıda sunulan mekânlara daha soyut sorgulamalar getirmek üzere analiz yapılmıştır. İzleyicinin film izleme deneyimden yapabileceği çıkarımlar da göz önünde bulundurularak, sonuç bölümünde bu konuyla ilgili değerlendirmeler tartışılmıştır. Beş Vakit, mekan ve zaman öğesine dair çoklu okumalara olanak verebilen bir anlatı olması dolayısıyla ve soyut anlamlandırmalara olanak tanıması nedeniyle incelemede yer almıştır. 


\section{Sonu Gelmez Mekânların ve Zamanların Çocuklarıydılar}

Beş Vakit (Reha Erdem, 2006), Yakup, Ömer ve Yıldız adlı çocukların ergenlik döneminde köylerinde yaşadıkları deneyimlere odaklanmaktadır. Çocukların gözünden köy yaşantısı, ebeveynle ilişkiler, doğa, taşra yaşantısı gibi olgular izleyiciye sunulmaktadır. Anlatıda üç çocuk karakter, başkarakterdir. Yakup, köyün öğretmenine âşık ailenin tek oğlu bir çocuktur. Hamile annesine zaman zaman yardımcı olan Yakup'un babasıyla ilişkileri iyi değildir. Baba karakteri de kendi babasının otoritesi altında yaşayan ve babasının itaatlerine uymadığında azar işiteren, sesi çıkmayan, edilgen bir karakterdir. Yakup'un babasının, babasıyla olan ilişki biçimi onun oğlu ve eşiyle olan ilişki biçimini de kötü yönde etkilemektedir. Çünkü, babasından işittiği azarlarla kendine olan güveni eksik olan baba karakteri, bu durumun hıncını ailesine karşı otoriter şekilde davranarak almaktadır. Yakup'un en yakın arkadaşı Ömer ise, Yakup gibi baba otoritesi altında büyümektedir. Babasıyla ilişkisi iyi olmayan Ömer, babasına karşı kin ve nefret beslemektedir. Babanın, küçük kardeşi Ali’ye gösterdiği ilgi ve yakınlığı, Ömer babasından görememektedir. Baba karakterinin Ömer'e karşı davranışlarındaki eleştirel tavır, Ömer'in babasına karşı nefret beslemesine sebep olmakla birlikte onu öldürmeye kadar giden bir hissiyatı Ömer'e hissettirmektedir. Hasta babasının ilaçlarının içine ilaçlar katarak, pencereleri açık bırakarak onun daha fazla hastalanmasına sebep olarak babasının ölmesini bekleyen Ömer'in kini ve nefreti çocukların ebeveynlerine karşı gizledikleri gizli duyguları yansıtmaktadır. Köyün imamı baba, eğitime önem verse de çocuklarına karşı davranışlarında tutarsız ve ayrımcı bir karakteri sergilemektedir. Ali'nin, Ömer'den daha zeki oluşu, baba karakterinin Ali'yi sürekli övmesine neden olurken, Ömer'in kendisini kötü hissetmesine yol açmaktadır. Baba, Ömer'in kendisine karşı beslediği nefret duygularının boyutlarından habersizdir. Oğlunun ona karşı mesafeli duruşunu ise sorgulamamaktadır. Yıldız karakteri, yeni doğan kardeşine bakmakla yükümlü, aynı zamanda okulunu da devam ettirmekte olan bir çocuktur. Annesinin kardeşiyle ilgilenmesi gereken durumlarda kardeşine bakan Yıldız, okula gittiğinde yorgun düşüp, uyuyakalmaktadır. Kardeşinin mamasını hazırlayan, onu yediren, gezdiren, altını değiştiren Yıldız adeta küçük bir anne gibidir. Ödevlerini yapması gerektiği zamanlarda ev işleriyle ilgilenen Yıldız, domestik ev işlerinin küçük yaşta sorumluluğunu almıştır. Yakup ve Ömer'in aksine Yıldız'ın babasıyla ilişkileri çok kuvvetli ve iyidir. Ancak burada dikkat çekici olan, Yıldız'ın babasının anlatıdaki otoriter baba figürlerine oranla daha edilgen ve kırılgan oluşudur. Yıldız'ın babası, eşine karşı daha anlayışlı ve hoşgörülüdür, babasından işittiği azarları sineye çeken ve kabullenen bu edilgen baba karakteri, köydeki baba karakterlerinin ataerkil yapısını ters yüz etmektedir. Üç çocuğun hayatlarının odak noktasında var olan zorluklarla köy yaşantısının doğallığı anlatıda verilirken, köyün ataerkil bir düzene sahip oluşu da vurgulanmaktadır. Köyde erkeklerin sözü geçerken, baba figürüne saygı gösterilmekte, yetişkin bireyler dahi babalarına itaat etmektedirler. Ataerkil düzenin fazlasıyla hissedildiği köyde, yetişkin erkek bireylerin dahi babalarına karşı seslerini çıkaramamaları ve konuşamamaları, onların aileleriyle olan ilişkilerine yansımakta ve çocukların iç dünyalarını çatışmalarla doldurmaktadır. 


\section{Heterotopyalarından Ufka Bakan Çocukların Zamanları ve Mekânları}

Film anlatısında zaman ve mekân kullanımı izleyiciyi sorgulamalara yöneltecek şekilde ve uzun düşünme süreçleri geçirtecek biçimde sunulmuştur. Yönetmen filmin zamansal algısını epizotik anlatımla beş vakte ayırarak sunmaya çalışmıştır. İzleyici sabah, öğle, akşam, ikindi, gece vakitlerini; güneşin doğuşu, ezanın okunuşu, güneşin batışı ve ayın görünümüyle görebilmektedir. Böylece olması gereken doğal yaşamdan uzak yaşayan şehir insanı, filmdeki zaman algısının sunumuyla doğal zaman algısının yaşantılanmasını somut biçimde hissedebilme ihtimaline kavuşmaktadır. Gündelik yaşantı içerisinde bireylerin tekrara dayalı edimlerle hayatı deneyimlemeleri ve bu deneyimi dünyanın hızlı ritiminden kopuk biçimde yaşamaları, mekânların da kendi içinde yaşadıkları ritmi izleyiciye hatırlatmaktadır. Mekân ve zaman ile karakterlerin kurduğu ilişkiler, doğal olanı sunarken, izleyici de gündelik yaşam içerisindeki zamanın akışı ve mekânların algısıyla ilgili düşünme sürecine girebilmektedir. Bu bağlamda film, gündelik hayatın akışıyla ilgili sorgulamalara da olanak vermektedir. Henri Lefebvre gündelik hayatın tekrarlardan oluştuğunu belirtir, mekanik hareketler olarak açıkladığı ellerin, vücudun hareketleri, rotasyonlar veya geliş-gidişler, edimsel tekrarları içerirken; saatler, günler, haftalar, aylar, yıllar, çizgisel tekrarlar, döngüsel tekrarlar, doğal zaman ve akıcı zamanlar da zamana dair tekrarları göstermektedir. Lefebvre, gündelik hayatın tekrarın bir değişkesi olup olmadığını sorgularken, bu hayat içinde tekrarların bir araya geldiği bir mekâna mı tekabül ettiğini de sorgulamaktadır (Lefebvre, 2007, s. 29). Film anlatısındaki karakterlerin tekrarlanan edimlere dayalı gündelik yaşantıları, dünyadan izole şekilde bir kara parçası üzerinde (köy) vücut bulmaktadır. Bu bağlamda, Michael Foucault'nun heterotopya kavramı anlatıda kullanılan mekân öğesinin anlamlandırılmasında rol oynamaktadır. Heterotopi, Yunancada hetheros ve topos (yer) kelimelerinden türetilerek tıp biliminde, dokuların ya da organların normalden farklı yerlerde bulunmasıyla karakterize anomali olarak tanımlanmıştır (Dökmeci, 2005, s. 155). Bu tanımlamadan hareketle, Foucault heterotopi kavramının tıp bilimindeki anlamını mimarlıkla ilişkilendirerek kullanmıştır. Bu minvalde, mekânların normalden farklı yerlerde bulunuşu, Foucault'nun heterotopya kavramını geliştirirken birbirinden farklı mekân varyasyonlarını yorumladığı mekânların anlam içeriklerinin birbirinden farklılıklarını ve ayrıksılıklarını hatırlatmaktadır. Henry Urbach ise, kavramın mimarlık alanına 1970'lerde Demetri Porphyrios, Manfredo Tafuri, Georges Teyssot gibi mimarlıkla ilgili teorisyen kişilerin metinleriyle girdiğini belirtmiştir. Urbach heterotopyaların, sosyo-mekânsal rejimlerin kurumsal olarak aleyhinde bir tavır sergilediklerini, ancak aynı zamanda onlara bağlı olduklarını da belirtmiştir (Urbach, 1998, s. 347-348).

Foucault, Öteki Mekânlara Dair (1986) adlı eserinde ütopya ve heterotopya kavramlarını açıklarken heterotopyaları altı şekilde ayırmıştır. Ütopya olanlar, gerçek yeri olmayan mahallelerdir. Kriz heterotopyaları, hiçbir yere işaret eden heterotopyalardır, bireylerin davranışlarının sapma olarak kabul edildiği durumlarda yerleştirildikleri sapma heterotopyaları ise kriz heterotopyalarının yerlerini 
almaktadır. Bir araya gelmesi imkânsız birkaç mekânın üst üste bindirilmesiyle oluşan ve en eski örneğinin bahçelerde görülebileceği heterotopyalar da vardır. Biriken zamanları içinde taşıyan heterotopyalar, açlıp kapanma sistemiyle çalışan heterotopyalar ve yanılsama mekânlarının yaratılması ya da mükemmeli yakalamak için yaratılan giderme heterotopyaları ve diğer mekânlarla ilişkileri içerisinde işleve sahip olan heterotopyalar, diğer heterotopyalardır (Foucault, 2017, s. 7-15). Film, zamanın birikimine bağlı ve zamanın en uçucu, süreksiz haline işaret eden, mutlak olarak şimdiki zamana ait heterotopyaları sunan panayır yerleri gibi boş mekânları, festival ve ebediyen biriken zaman heterotopyalarını bir araya getiren mekânları izleyiciye sunmaktadır. Çünkü Foucault'nun da dediği gibi bu mekânlar, hayatın yeniden keşfi zamanını hem ortadan kaldırmakta hem de aynı şekilde zamanın yeniden keşfini de göstermektedir. Bu minvalde, zamanın keşfi olgusu önemli hale gelmektedir. Foucault'ya göre zamanın keşfi, insanlığın tarihine dolaysız bir bilgi şeklinde ulaşılabildiğinin göstergesi olmaktadır (Foucault, 2017, s. 13). Mekân kavramının bu bağlamda zaman kavramıyla iç içe geçmişliği her iki kavramında birlikte incelenmesinin temelini oluşturmaktadır. Foucault'nun heterotopya kavramıyla ilgili yorumlar yapan ve düşüncelerini paylaşan birçok teorisyen bulunmaktadır. Kavramın anlamı ve çoklu okumalara olanak tanıması, Foucault'nun fikirlerinin tartışılmasına neden olmuştur. Heterotopya kavramı hakkında düşünceleri belirten teorisyenlerle, zaman kavramına ilişkin düşüncelerini belirten teorisyenlerin fikirleri filmin anlatısıyla birleşmektedir.

Peter Johnson, Foucault'nun açıkladığı heterotopya çeşitlerinin rahatsız edici mekânlar olduklarını söylemiştir. Bu kavramla, insanlar, içinde yaşadıkları mekânla ilgili kendilerini sorgulamaya yönlendirmişlerdir. Evimiz gibi hissettiğimiz mekânlarla ilgili içine girdiğimiz sorgulamalar, Johnson açısından önem taşımaktadır. İçeride olma durumuyla ilgili yaşanan bu sorgulamalar insanların hislerini de kurcalamaktadır. Heterotopyalar, saf bir formda olmamakla birlikte, değişik kombinasyonlar içermekte ve birbirleriyle çarpışan ilişkiler yaşamaktadırlar, tüm bunların ötesinde, mekânsal ve zamansal birlikleri de bozmaktadırlar. Güçten kaçabilmenin yollarını sunabilen heterotopyalar Johnson'a göre rotalar da önermektedirler (Johnson, 2006, s. 84-86). Johnson'un heterotopyalarla ilgili çıkarımları, insanların yaşadıkları mekânla ilgili sorular üretmesine olanak tanımakla birlikte heterotopyaların birbirlerinden tamamen bağımsız olmadığını da göstermektedir. Johnson'un düşüncelerini yorumlayan Robert J. Topinka, Johnson'un düşüncelerinden hareketle heterotopyaların, güç ilişkilerinin ayrımını kavramanın ve bununla ilgili farklı düşünebilme girişimlerinin ortaya çıkabileceğini belirtmiştir. Ancak bu durum, tekrar düşünme sürecinin güçten kaynaklanan özgürlüğü sağlayamama intimalinin de göz önünde bulundurulması gerektiğini göstermektedir. Çünkü Topinka'ya göre, bu heterotopyaların güçten ayrı geçici geçişler olarak anlaşılması gerekmektedir. Öteki Mekânlara Dair adlı çalışmasında, heterotopyaların diğer mekânlardan bağımsız olarak var olamayacağını söyleyen Foucault, gücün de bu mekânların içinde bulunduğunu belirtmiştir (Topinka, 2010, s. 60). 
Kevin Hetherington'dan aktaran David Harvey ise, Hetherington'ın heterotopyaları farklı düzenleme alanları olarak özetlediğini belirtmektedir:

Heterotopyalar toplumsal dünyanın bir kısmını var olandan değişik bir biçimde düzenlerler. Bu farklı düzenleme onlara Öteki imi yükler ve bir şeyleri yapmanın alternatif yolu olarak örnek teşkil etmelerine olanak tanır... Heterotopyalar dolayısıyla toplumsal düzenleme süreçlerinin tam da bu olduklarını, yani şey değil süreçten ibaret olduklarını gün ışığına çıkarırlar (Harvey, 2011, s. 226).

Bu bağlamda, çocukların köydeki yaşamları ve hayatla kurdukları bağ anlatılırken, köyün mekân olarak dünyadan ayrıksı biçimde sunuluşu Hetherington'ın düşüncelerine paralellik göstermektedir. Yakup, Ömer ve Yıldız'ın ormanın içinde geçirdikleri zamanlar, uçurumun kenarından denizin maviliklerine, göğün yüksekliklerine baktıkları anlar, birlikte hayatı dostça deneyimledikleri hayvanlarla panayır yerindeymişçesine mutlu ve huzurlu halleri onların heterotopyalarını yaratmaktadır. Çocukların iç çatışmalarında yaşadıkları dertlerden ayrı olarak, içlerindeki huzuru bulmak için doğaya çıkmaları, yapraklarla örtünerek, çimlerde yatarak kendilerini dinlemeleri onların mutlak ve şimdiki zamanına tekabül etmekte ve içinde bulundukları mekânla bir taraftan da zamanın yeniden keşfini hissetmektedirler. Hem bir festival içindeymişçesine yorucu dünyadan uzakta yaşarlarken hem de ebediyen biriken zamanın heterotopyası içinde zamanlarını istedikleri gibi harcayabilmektedirler. Yönetmenin olay örgüsünün merkezinde sunduğu köy mekânı aynı zamanda öykünün de odak merkezinde bulunan olayların geçtiği bir mekândır. Hem olay örgüsü mekânı olarak hem de öykü mekânı olarak köy, izleyicinin zaman ve mekânla ilgili bilişsel algılamalarını harekete geçirici bir işlevsellik göstermektedir. Yönetmen, bu bağlamda anlatının zaman ve mekânını izleyiciye sunarken seçtiği dekupajlarla filmin anlamlandırılmasında önemli rol oynamaktadır. Noel Burch, dekupajı (découpage), çekilmiş olan filmlerden seçilerek oluşturulan mekân parçalarının sıralanması olarak belirtmektedir. Filmin spesifik formunun analiziyle, dekupaj kavramı sayesinde zaman ve mekân kavramlarının anlatıdaki özünün anlaşılması da sağlanmaktadır (Burch, 1981, s. 4). Bu bağlamda, Beş Vakit'te sunulan zaman öğesinin anlatıdaki dizilimi klasik anlatı sinemasında kullanılagelen düz bir çizgide ilerlememektedir. Bazı sahnelerde uzun sekanslarla verilen mizansenler, anlatı zamanını uzun tutarken, izleyicinin de zaman ve mekân kavramlarına dair sorgulamalarını içselleştirmesini sağlamaktadır. Anlatıda sunulan heterotopyaların ve zaman olgusunun sinematik dilde tezahürü klasik anlatı yapısını dekonstrükte eden biçimsel ve içeriksel anlatı stratejileriyle açıklanabilmektedir. Çocuk karakterlerin kesintisiz kamera çekimleriyle takibi, izleyiciyi onların dünyasına sokmakta ve onlarla özdeşleşim kurmalarına olanak vermektedir. Erdem, karakterlerin yürürken, koşarken uzun plan/sekanslarla takibinin nedenini, köyün coğrafyasında çocuklarla birlikte o köyü oluşturmak için bu sekansların kullanılması gerekliliğine bağlar. Geniş planların da anlatıda çok kullanılması, doğanın kendisinde var olan genişlik hissine bağlanmaktadır (Yücel, 2009, s. 151). Erdem, sinematografik açıdan anlatıyla ilgili yaptığı açıklamalarda, sinematik dilde heterotopyanın sunuluşunu dair sinematografik çıkarımları düşündürtmektedir. 
Öğretmenlerinin doğanın içerisinde doğadan örnekler vererek çocukları bilgilendirmesi gibi, çocuklar da hayatın içinde yaşama dair dolaysız bilgiyi kendi heterotopyalarında edinmektedirler. Kendi yaşadıkları mekânın izini sürerek yaşadıkları mekânla bütünleşmektedirler. Heterotopya kavramını yorumlarken, Lefebvre'nin yaşanan mekân kavramı bu bağlamda akla gelmektedir. Yaşanan mekânlar da heterotopyalar gibi çoklu okumalara olanak veren ve insanların yaşadıkları mekânları kendi öznellikleri içinde değerlendirmeye açık mekânlar olarak sunan mekânlar olmaktadır. Lefebvre'ye göre, temsil mekânları yani yaşanan mekânlar; mekâna eşlik eden imgeler, sembollerle, oturanların, kullananların mekânları olmakla birlikte bazı sanatçıların, o mekânı tarif edenlerin de (yazarlar, filozoflar) mekânı olmaktadır. Temsil mekânları, yaşanmışlığı içermektedir ve kökeni tarihtir; bir halkın ve bu halka mensup bir kişinin tarihini ifade etmektedir. Ego, yatak, oda, konut, ev, meydan, kilise, mezarlık, yaşanan mekânların örnekleridir (Lefebvre, 2014, s. 68-71). Yakup'un, Ömer'i dayısının ormanlık alan içindeki mezarına götürüp mezar başında dua okumaları, onların yaşanan mekânlarıyla heterotopyalarını iç içe geçirmektedir. Mezarlar da, Foucault'nun belirttiği üzere, toplumun ya da köyün diğer mahalleriyle gerçekdışı mekânlardır (Foucault, 2017, s. 10). Çocuk karakterler, köyün içinde bulunan mekânlarla, çevresini saran ormanlık alanlarla, bu garip heterotopyalara giriş çıkışlarıyla yaşanan mekânlarını zihinlerinde somutlaşıırmaktadırlar. Yönetmen, çocuk karakterlerin iç dünyalarını heterotopyalarla birlikte sunarken, izleyicinin sadece ekran mekânına yani sabit çerçeveye bakmamasını sağlamaktadır. Çünkü doğaya ilişkin sahnelerin sabit çerçeve içinde uzun planlarla ve doğaya ait detayların ayrıntı çekimlerle sunumu, izleyicinin doğayla birlikte karakterlerin doğayla ilişkisini de detaylandırmalarını sağlamaktadır. Stephen Heath, kod ve sistemlerin sinema tarihi içindeki gelişiminden bahsederken, mekânın izleyici tarafından nasıl algılandığına dair önemli çıkarımlarda bulunmaktadır. "Film görüntülerin toplamı değil, zamansal bir formudur" diyen Heath, hareketin yalnızca kendi içinde algılanmadığını, mekânın içinde sınırlandırıldı̆ını, izleyicinin yalnızca hareket edene karşı tepkisel olmadığını söyler ve hareketin algısında da sabit çerçevelerin izleme sürecinde izleyici tarafından varsayıldığını belirtir (Heath, 2017, s. 4). Dolayısıyla filmi izleyen izleyici sabit çerçevenin içinde gerçekleşen hareketleri ve çerçevenin içindeki imgeleri izlerken diğer taraftan zihinlerinde bu mekânların içinde sunulan görsellerin ve metaforların da neleri ifade ettiğini anlamaya çalışmaktadır. Çocuk karakterlerin yaşanan mekânları zihinlerinde somutlaştırdıkları gibi, izleyici de sabit çerçeve içindeki imgeleri ve karakterin iç dünyasını kendi zihninde somutlaştırmaktadır. David Bordwell, Heath'i de referans göstererek kamera hareketlerinin yönetilmesinde izleyicinin bakışının ve kameranın bakışının önemini vurgulamaktadır (Bordwell, 2017, s. 23). Bordwell'in de düşünceleri minvalinde, kameranın yönetimi sonucu ortaya çıkan görsellerde kameranın bakışının önemi ortaya çıkmaktadır. Ancak izleyicinin bakışı, film izleme deneyimi süresince kameranın baktığından daha farklı olabilmektedir. Film izleme deneyimi içinde izleyicinin zihninde yer alan kodlar, uylaşımların onlara sunduğu öğelerle birleşerek anlatı mekânları hakkında yorumlama ve sorgulama süreçlerini de üretecektir. Bu nedenle anlatı mekânlarının analizlerinde çoklu perspektiflerle 
okumalar yapmak gerekli hale gelmektedir. Nitekim çocuk karakterler anlatının merkezinde olduğundan dolayı bu bağlamda farklı mekân intimallerinin örnekleri açısından da sorgulamalar ortaya çıkmaktadır. Edward Soja, hem Foucault'nun heterotopya kavramını hem de Henri Lefebvre'nin yaşayan mekân kavramını yorumlayarak başka bir mekânın gerekliliğinden söz etmektedir. Edward Soja, üçüncü mekân olarak nitelendirdiği bir mekândan söz ederken bu mekânı Foucault'nun heterotopyasıyla karşılaştırmaktadır. Bunu yaparken de Henri Lefebvre'nin yaşayan mekân kavramını da temel almaktadır. Foucault heterotopyaları, içinde yaşadığımız, kendi hayatlarımızı aşındıran ve içine bizi çeken, zamanı ve tarihi de oluşturan mekânlar olarak açıklamaktadır. Lefevbre ise, heterojen alanları; mekân, bilgi ve güç trialektikleriyle doldurmaktadır (Soja, 1996, s. 15). Soja'nın nitelendirdiği üçüncü mekânlar, ötekileştirilmişlerin mekânı olagelmektedir. Soja, üçüncü mekânın, mekân olarak içerdiği anlamlarında ve gösterdiklerinde, değişik düşüncelere yol açtığını iddia eder, insan hayatında mekânsal olarak yer, lokasyon, bölge, toprak, çevre, ev, şehir, yöre, arazi ve coğrafya gibi kavramları kapsadığını ve oluşturduğunu da ifade eder (Soja, 2016, s. 1). Bu minvalde, filmdeki çocuk karakterler de sundukları iç dünyalarıyla, yetişkinlerden farklı, görünürlügü yok sayılan bir dünyayı izleyiciye sunmaktadır ve üçüncü bir mekânın içinde yaşıyormuşçasına hareket etmektedirler. Köy, şehrin kaosundan uzaklığıyla, aynı zamanda şehrin içinde var ettiği kolaylıklardan da uzak oluşuyla hem bir izole mekân görevi üstlenmekte hem de zor koşullarıyla üçüncü bir mekânın varlığını hatırlatmaktadır. Gerek karakterlerin iç çatışmaları gerekse de mekânın kullanım stratejisi Soja'nın üçüncü mekân kavramını izleyiciye sunmaktadır. Homi K. Bhabha ise, ötekiler için, madunlar için farklı kültür ve farklı kamusallıkların konuşabilmesinin mümkün olup olmadığını sorar, 'ben' ve 'sen'in yer aldığı üçüncü bir mekâna doğru hareket etmenin gerekliliğini belirtir (Bhabha, 2016, s. 20). "Ben'in ve sen'in yer aldığı, ötekilerin, madunların var olabileceği üçüncü mekânlara nasıl hareket edilmelidir ya da bu mekânlar nasıl yaratımalıdır?" diye sorarken, anlatının çocuk karakterleri yaşanan mekânlarında yarattıkları heterotopyalarıyla bu üçüncü mekânı oluşturmaktadırlar. Hatta en mükemmeli dahi oluşturabilmenin keyfini sürmektedirler. Foucault'nun en mükemmel heterotopya olarak nitelendirdiği gemiler, bu bağlamda akla gelmektedir. Foucault'nun en mükemmel heterotopya olarak nitelendirdiği gemilerde, maceralar tezahür eder ve korsanlar vardır, gemisiz uygarlıklarda ise, rüyalar solarken, maceranın yerini casusluk alır, korsanların yerini ise polisler almaktadır (Foucault, 2017, s. 15). Filmde de ufku uçurumdan izleyen karakterler bir geminin en önündeymişçesine ileriye bakmaktadırlar. Köylerinden çıkmadıkları gibi, denizin maviliklerine bakarak kendi alanları içindeki heterotopyada yaşamaktadırlar. Ormanlarda kaybolup, bitkilerin içinde saklanarak adeta korsanlar gibi kendi inlallerini yaratmaktadırlar. David Harvey bu kavramla, Foucault'nun yersel bir ütopyanın yok mekânından kaçmasına olanak tanıdığını belirtmektedir. Seçeneği, çeşitliliği ve farklılı̆ı vurgulayan mekânsal oyunların eşanlı olarak var olabileceği fikrinin de benimsenmesi açısından heterotopya kavramı, Harvey'e göre önemli bir kavram olagelmektedir. Foucault'nun göstermiş oldukları, ötekilik, başkalık ve alternatiflerin keşfedilebileceği bol mekânları sunmaktadır. Hâkim 
toplumsal düzenle bağların kesilebileceği, zayıflatılabileceği veya tamamıyla tersine çevrilebileceği intimalini de göstermektedir. Ötekilik mekânlarında vuku bulan her şeyin ilgi çekici olduğu ve bazı açılardan kabul edilebilir veya uygun olabileceği varsayımı da Harvey'in heterotopya kavramı hakkındaki düşünceleridir (Harvey, 2011, s. 226-227).

John Urry ise, yaşanan mekânları şöyle yorumlamaktadır:

Hâkim kavramlara karşıtlık ya da düşmanlık gerektiren karmaşık simgeler ya da nosyonlar. Bu nosyon, kırsal alanı bir heterotopya, değişen anlamlar ve dokunaklı anılar taşıyan, bir karanlık köşeler, gizem yeri, bir labirent olarak görür. Bu son nosyon, kırsal alanın planlanmaması ya da homojenleştirilmemesini, yorumlanmamasını ve ziyaretçilerin umulmadık anılar karşısında tökezlemesine izin verilmesini içermektedir. Kırsal alan elbette bu üç kavramın hepsidir. Bu kavramlar arasında ve onların birini ya da diğerini uygulamak ya da korumakla ilgili çıkarlar arasında uzun süredir devam eden çatışmalar vardır (Urry, 2015, s. 336).

Urry'e göre, yaşanan mekânlar, mekân çevresindeki simgesel farklılaşmaları, kolektif fantezileri, hâkim pratikler karşısında direnişleri, bireysel ve kolektif ihlal biçimlerini de kapsamaktadır (Urry, 2015, s. 47). Anlatıdaki çocuk karakterler, ebeveynleriyle yaşadıkları çatışmalarla ve onlar tarafından ezilmeleriyle öteki madunlar olarak üçüncü mekânı kendileri yaratmışlardır. Yarattıkları bu üçüncü mekânda Urry'nin de belirttiği gibi bireysel ve kolektif inlal biçimlerini kendileri geliştirmişlerdir. Urry, yaşanan mekânların değişiminden ve dönüşümünden bahsederken alternatif mekânsal pratiklerin de ortaya çıkışını düşündürtmektedir. Heath, Urry'nin düşüncelerine paralel biçimde, anlatıda sunulan mekânların da izleyici açısından kendi içinde tekrar düzenlendiğini belirtmektedir. Klasik sinemada bağlayıcı bir kavram olarak mekânın konstrüksiyonu, izleyicinin bakış açısında filmin anlatı olarak yerini alması konusundaki çıkarımdır; bu çıkarım sürekli bir tekrar bulma sürecini içerir; mekânın düzenlenmesi, yönlendirilmesi, sürdürülmesi ve tekrar oluşturulmasıdır (Heath, 2017, s. 17). Heath'in klasik sinema üzerinden açıkladığı mekânın konstrüksiyonu, çağdaş anlatı sineması izleyicisi açısından daha geniş perspektiflerle okunabilir. Dolayısıyla film anlatısında sunulan mekânlar sadece anlatının öğesi olarak kalmamaktadır, öyküyü ve karakterleri de etkileyen işlevsel bir anlatı öğesi olan mekânlar alternatif mekânların da yaratımını sorgulayan bir etki göstermektedir. Bu minvalde, çocuk karakterlerin mekânlardaki sunumu üçüncü mekânların nasıl yaratılacağına dair önceleme yapmaya olanak sağlamaktadır. Fırat Yücel, Reha Erdemle yaptıkları söyleşide, mekânın yönetmenin filmlerinde önemli yere sahip olduğunu belirtmesi üzerine Erdem, Beş Vakit'in senaryosunu yazarken senaryonun çıkışının temelini filmin çekildiği köye bağlamıştır. Erdem, Çanakkale'nin yamaçlarındaki Kozlu köyünü gördükten sonra filmin o köye yazıldığını belirterek, mekânın anlatının içeriğinde ne kadar önem arz ettiğini vurgulamış olmaktadır (Yücel, 2009, s. 149). Bu bağlamda, anlatı mekânları oluşturulurken olay örgüsü mekânı, öykü mekânı, ekran mekânı yani sabit çerçeve mekânı yönetmen tarafından köyün görsel 
zenginliğini hem ön plana çıkaracak biçimde hem de anlatının odak merkezine alınan köyün sunumunda sinematografik açıdan üzerinde ince düşünüldüğü belli olan sekanslar ve sahneler aracılığıyla izleyiciye sunulmuştur. Ormanlık alanların görüntüleri, vakitlerin dönüşümünde bulutların ve gökyüzünün görkemli hali, doğanın vahşi ve cezbedici havası, zaman zaman yavaş pan hareketiyle sunulurken, zaman zaman da kameranın sabit duruşunda uzak planlardan alınan görüntülerle doğanın şiirselliği kurgulanmıştır. Yönetmenin, şiirsel görüntülere daha da şiirsellik eklediği Arvo Pärt müzikleriyle izleyici, doğanın incelikle kurgulanmış görüntüleri eşliğinde başka bir mekânın ve zamanın seyrine ortak olmaktadır. Erdem, kullandığı müziğin görsel bir fon olduğunu belirtir. Çerçeve dışının ilahi olanı ima ettiği gibi Pärt'ın müziğinin de ilahi olduğunu söyler (Yücel, 2009, s. 167). Erdem, dış dünyanın gerçekliğinden farklı olan çocuklara dair gerçekliği sunarken, onların doğaya kaçışını sinematik dilde yine doğanın görkemli güzelliği içinde temsil etmektedir. Pärt'ın müziğinden ezan sesine geçişin birbirine kaynaştırılarak sunumu gibi, izleyici de dini kavramlara göndermeler yapan anlatımı işitsel açıdan incelikle kurgulanmış, yönetmen tarafından ilahi olarak nitelendirilen bir ses tasarımıyla izlemektedir. Alternatif mekân olanaklarının da sorgulandığı anlatıda çocuk karakterler, dış dünyanın gerçekliğinden zaman zaman koparak kendi dünyalarını ormanlık alanların içinde yaratarak üçüncü mekânın hissini yaşamakta ve nasıl yaratılabileceğine dair izleyiciye ipucu vermektedirler. Yakup, âşık olduğu öğretmenin, babası tarafından voyoristik biçimde izlendiğini gördügünde yaşadığı hayal kırıklığı sonrasında, Yıldız, annesiyle babasının sevişme seslerini duyup onları skopofilik bir konumda izlemeye gittiğinde, Ömer, kardeşinin yaralanmasına neden olduğu için babasından dayak yediğinde doğaya sığınır. Doğa, onların kaçış yerleri, sığınaklarıdır. Toplumsal düzenin kuralları, kalıplaşmış yargıları içerisinde sürreal dünyaların keşfine çıkarak, zamanın ucu açık kısmını üzerlerine örttükleri yapraklarla donatarak, suyun sesini dinleyerek, kuşun ötüşünü duyarak, ormanın sesli sessizliğinde ikamet etmektedirler. Yakup, Ömer ve Yıldız'ın yaşanan mekânları, köye ait her imgeyle bütünleşmektedir. O kadar çok bütünleşmektedirler ki çimlerin üzerine uzandıklarında, yaprakları üzerlerine örttüklerinde her bir yaprak tanesi, çimen parçası onların başka bir organına dönüşmekte, doğaya ve köylerine dair her şeyi içselleştirmektedirler. Anlatı, çocukluktan ergenliğe geçiş aşamasında çocuk karakterlerin yaşadıkları buhranları, cinselliklerini keşfetme anlarında ebeveynlerine karşı hissettikleri çatışmalı duyguları saklayacakları ve kendilerinin de saklanacakları heterotopyaları sunmaktadır.

Karakterlerin yaşadıkları alan, denize kıyısı olan bir köy olsa dahi karakterlerin denizle hiçbir bağlantı kurmamaları da anlatıda köyü odak merkezine yerleştirmektedir. Sağlık sorunlarıyla karşılaştıklarında doktor olmadığı anlaşılabilen bir karakterin hastaya müdahale etmesi veya köyde yaşanan bir sorun sonucunda intiyar heyetinin toplanarak karar almaya çalışması gibi durumlar, köyün kendi içinde kurduğu ataerkil düzeni izleyici göstermektedir. Devlete ilişkin tek mekân okul olarak sunulurken, öğretmen ise devleti işaret eden tek memur olarak temsil edilmektedir. Keza öğretmen dahi doğanın içinde, 
doğadan verdiği örneklerle ve okuttuğu parçalarla köy insanlarının yaşantıladığı doğallığı kendi içerisinde tekrarlatmaktadır. Foucault'nun belirttiği gibi, kendine has mikrokozmos içerisindeki bahçelerinde yaşayan bu karakterler, ormanlık alanlardan ufka bakarken ve gündelik yaşantılarını sürdürürken dünyanın hem en küçük parselinde nefes almakta hem de dünyanın külliyetinin de içinde var olmaktadırlar. Lefebvre'e göre, kozmolojik gerçekliğin içinde zaman ve mekân yer aldığı gibi enerji de yer almaktadır, zaman ve mekânı çatışmalı kılan ise enerjidir. Bu üç kavramın aralarındaki ilişki kavramlara evrensel bir somutluk getirmektedir (Lefebvre, 2017, s. 88). Foucault'nun yorumladığı mikrokozmos, mekân tahayyülleri hakkında soyut düșünme sürecine katkıda bulunurken, Lefebvre'in kozmolojik gerçekliğe dair analizi zaman, mekân ve ayrıca enerji kavramını somutlaştırmaktadır. Enerji kavramının film anlatısındaki tezahürü karakterlerin edimleri ve sabit çerçeve içindeki devinimleriyle örtüşmektedir. Çocuk karakterlerin ormanlık alanlar içindeki koşuşturmaları, dağ yamaçlarında bağırarak şiir okuduklarında seslerinin ekosunu doğanın içinde duymaları, mekânların enerjisini ve ritimlerini izleyiciye sunmaktadır. Doğaya ait seslerinin anlatı süresince fonda devam ederken ezan sesiyle doğaya ait seslerin birbirine karışımı ve ezan sesinin başlamasıyla daha vurgulu biçimde sesin kurgusunda ezanın duyuluşu anlatının kesintiye uğramasına sebep olmaktadır. Düz bir anlatı çizgisinde ilerlemeyen anlatı, ses kurgusuyla da anlatının eğimli bir ritimde oluşunu göstermektedir.

Anlatının eğimli ritmiyle birlikte, zaman zaman yalnızlıklarıyla kendilerini dinleyen çocukların hareketli anları heterotopyaların sinematik bağlamda anlatı stratejileriyle nasıl sunulduğuna dair fikir vermektedir. Heath film anlatısındaki mekânların, çerçeve içinde sunulurken çerçeve dışında görünemeyenlerin teknik nedenlerden dolayı görünmediğini ve çerçeve içinde yer almadığını anlatmaya çalışmakta ve anlatı mekânının aslında çerçevenin de ötesinde limitlerinin olduğunu öne sürmektedir (Heath, 2017, s. 8). Yönetmen, mekânların sunumunda geniş planlarla aldığı doğa görüntüleri eşliğinde, ayrıntı çekimlerle sunduğu doğaya dair detaylarla izleyiciyi var olan çerçevenin dışını da tasavvur etmesini olanaklı kılmaktadır. İç çatışmalarıyla sunulan Yakup, Ömer, Yıldız, kendi dünyalarında bazı dertlere sahip olsalar da mutlu ve izole bir heterotopya içerisinde yine kendilerine ait küçük bir mikrokozmosu yaratabilmektedirler. İzleyici kendisine sunulan heterotopyalarda, çocuk karakterler gibi kendilerine ait mikrokozmoslarında öykü mekânın ötesindeki mekânları düşünebilmektedir. Urry, kırsal alanı, gizemin, anının ve sürprizin bir temsili mekânı olarak nitelendirmektedir ve bu tür yerlerin tüketilebileceğini, bitirilebileceğini, ziyan edilebileceğini ve yok edilebileceğini belirterek korunması gerektiğini vurgulamıştır (Urry, 2015, s. 337). Çocuklar kendi mikrokozmoslarını yaratırken, iç dünyalarında da heterotopik anıları çocuksu hayalleriyle kurabilmektedirler. Ormanlık alanlarda bireysel olarak yalnız kaldıkları anlarda yetişkin bireylerden farklı olarak dünyayı anlamlandırmaktadırlar. Bu bağlamda, Jorge Luis Borges'in Bellek Funes hikâyesi akla gelmektedir. Hikâyenin baş karakteri Funes, her şeyi detaylarıyla diğer insanlardan farklı biçimde hatırlamakla birlikte, şaşırtıı şekillerde anılarını aklında tutmaktadır ve 
bu tutma işlemini gerçekleştirirken kendi geliştirdiği dili kullanmaktadır. Topinka, bu kurgusal heterotopik belleğin, gerçek heterotopyalara biraz benzediğini belirterek, birçok mekânın bellekte iç içe geçtiğini söylemiş ve böylece bilmeye dair yoğunlaşmanın gerçekleştiğini öne sürmüştür (Topinka, 2010, s. 56). Bu bağlamda, çocuk karakterlerin hayatı algılama biçimlerinin yetişkinlere oranla daha detaylı olacağı intimali ortaya çıkmaktadır. Şimdiki zamanı yaşamaları, algılamaları, anılarını ebeveynlerinden farkı biçimde içselleştirmeleri, onların yalnız oldukları anlarda hayatı anlamlandırma biçimlerini de etkilemektedir. Kendilerine yapılan en küçük kötü hareketi unutmadıkları gibi, belleklerine kazıyarak bunları iç dünyalarında çeşitli hallerde yaşamaktadırlar. Funes gibi başka bir dili somut olarak geliştirmeseler de zihinlerinde ebeveynlerine karşı sorgulamalar üretirken, hayata karşı yarattıkları dille de bir taraftan içinde bulundukları durumları sorgulamaktadırlar. Bellekte yaratılan hayali heterotopyaların imkânsız ya da düşünülemeyen mekânlar oldukları söylenmiş ve sadece dilde yer alabildikleri belirtilmiştir (Johnson, 2006, s. 85). Yakup, Ömer ve Yıldız'ın da belleklerinde yarattıkları heterotopyalar, ebeveynleri tarafından düşünülemeyen mekânlar olmakta, ancak çocuk karakterlerin hayallerine yerleşen heterotopyalar olmaktadırlar. Funes, nasıl kendi dilini yaratarak, muazzam bir belleğe sahip oluyorsa, Yakup, Ömer ve Yıldız da belleklerinde yer alan zaman ve mekânların iç içe geçmişliğiyle kendi heterotopyalarına sahip olmaktadırlar ve Foucault'nun nitelendirdiği o mükemmel heterotopyada soyut heterotopik belleklerini oluşturmaktadırlar. Bellek Funes'te Borges, Funes'in zihnini şöyle tasvir etmektedir: "Biz bir bakışta, bir masa üzerinde üç şarap kadehini algılarız; Funes ise, asmayı, onu meydana getiren bütün yaprakları, filizleri ve üzüm tanelerini görüyordu." (Borges, 2015, s. 136). Yakup, Ömer ve Yıldı'ın, gördükleri, hissettikleri ve duyumsadıkları, yetişkinlerden o kadar farklıdır ki en ufak bir olguyu zihinlerinde Funes gibi detaylarıyla düşünerek ve hatta kendi hayallerinden öğeler katarak zenginleştirebilmektedirler. Çocuk karakterlerin tahayyülleriyle oluşturdukları heterotopyaları, toplumsal düzenin onlara baskıladığı kurallar bütününden ayrıksı biçimde zihinlerinde oluşmaktadır. Ebeveynleri ve köy ahalisi ise, yaşadıkları heterotopya mekânının içinde iktidar mekanizmasının söylemlerini tekrar ederek ve bunu edimlerine dökerek bu heterotopyanın farkına varamamaktadırlar. Bu bağlamda, anlatının yetişkin karakterleri açısından heterotopya iktidar mekanizmalarını gelecek nesillere aktaran bir işlev görürken, çocuk karakterler açısından sığınıp kaçtıkları alanları onlara sunar. Kadınların ikincilleştirildiği, erkeklerin yüceleştirildiği patriarkal düzende, yetişkin erkeklerin dahi babalarının karşısında yetişkinliklerini yitirdikleri görülmektedir. Herhangi bir işi beceremediklerinde babaları tarafından azarlanan ve aşağılanan yetişkin erkek karakterler var olan düzenin temsilcileri gibidir. Babalarla oğullarının çatışmaları bazen çocuk karakterlerin gözleri önünde cereyan eder. Ataerkil mekanizmayı içselleştiren Yakup ve Ömer, kız arkadaşlarına davranışlarında bu düzenin devam edeceğinin işaretini verirler. Cinselliği keşfetme çağında olan çocuklar cinselliğin keşfini ise, doğadaki hayvanların çiftleşmesi sırasında öğrenmeye çalışıllar. Üç erkek çocuk karakterle, iki kız çocuk karakterin, hayvanların çiftleşmesini izledikleri sahnede, erkek çocuklar kızların izlemesine izin vermeyerek onlara taş 
atar. Erkek çocukların, kız çocuklara karşı sergiledikleri davranışlarının temelinde yatan, ataerkil düzenin kurallarıdır. Ancak yine de oyun oynamak istedikleri zaman, konuşmak istedikleri zaman kız arkadaşlarıyla sosyalleşirler. Bu durum, heterotopyaların çocuklar açısından yetişkinler kadar baskı içinde görülmediğini işaret ederken ebeveynleri tarafından baskıyla karşılaştıklarında da kaçacakları alanları onlara sunmaktadır.

Karakterlerin, yaşadıkları mekân içerisinde zamanın akışını düşünmeksizin hayatlarını sürdürmeleri de anlatıda zaman olgusunun izleyici tarafından sorgulanmasına olanak tanımaktadır. Burch, anlatı zamanı ile film zamanı kavramlarının birbirinden farklı olduğunu ve diyalektik olarak da ilişkilendirilemeyeceklerini belirtmektedir. Ölçülebilir eksiltmeyle, sınırları olmayan bir eksiltmenin arasındaki farkın okuyucu açısından belirsizlik içerdiğini ifade etmektedir (Burch, 1981, s. 7). Bu bağlamda, film zamanı belli süre içinde izleyicinin filmi izleyebileceği süreyi gösterirken, anlatı zamanı yönetmenin anlatım diline göre değişkenlik gösterebilecek ve izleyicinin de anlatı zamanıyla ilgili düşünebileceği belirsizlikleri barındırabilir. Keza klasik anlatı sinemasının anlatı zamanı belli taslaklarla oluşturulurken, Beş Vakit gibi çağdaş anlatı yapısı içeren filmlerdeki anlatı zamanlarının inşasında klasik anlatı sinemasının uylaşımlarını yapısöküme uğratan anlatım dili tercih edilebilir. Böylece izleyici anlatı zamanını kendi anlamlandırabilir ve film zamanı sona erse dahi kendi içinde $\mathrm{O}$ anlatı zamanını yaşayabilir. Bu nedenle çağdaş anlatı sineması örneği oluşturabilecek bir filmin zaman öğesinin analizinde zaman kavramına dair daha felsefi sorgulamalar ortaya çıkabilmektedir. Sosyal bilimlerin birçok alanındaki teorisyenlerin kuramlar yaratmasında ve düşünceler üretmesinde temel olan zaman kavramının sinema anlatısındaki yeri, bu bağlamda önemli olmaktadır. John Locke'un zaman kavramıyla ilgili sorusu, kavramın içindeki felsefi anlamların çokluğuna işaret ederken, sinema anlatılarında kavramın incelenmesiyle ilgili geniş perspektifte düşünmenin gerekliliğini ortaya koymaktadır. Locke, "Zaman nedir diye sorulduğunda bir büyük insan Si non rogas intelligo (yani, hakkında düşünmeye yöneldikçe daha az anladığım) diye yanıt vermiştir ki bu, belki tüm diğer şeyleri açıklığa kavuştururken kendisi keşfedilmeyen bir şey olduğuna inandırabilir insanı, diyerek zamanı açıklamaya çalışmıştır (Locke, 2000, s. 244). Zaman ile mekân arasındaki ilişkiye de değinen Locke, mekân kavramı yerine uzam kavramını kullanmış ve zaman ile uzam arasındaki ilişkiye de değinmiştir:

Zaman genellikle evrendeki büyük cisimlerin, bilgisine sahip olduğumuz kadarıyla,
varoluş ve hareketleri ile ölçülen ve bir arada var olan, böylece de sonsuz sürenin
önemli bir parçası olarak ele alınır: Bu anlamda zaman duyulur dünyamızla başlar
ve biter. Yer de bazen bu dünya içinde sınırlı bir sonsuz uzay parçası ve böylece
yayılımın gerisinden ayrı olarak düşünülür. Ancak bunun yerden çok uzam diye
adlandırılması uygundur (Locke, 2000, s. 266-267).

Mikhail Bakhtin'in de öne sürdüğ̈ gibi, zaman ve mekân sanatta birbirinden ayrılmazlığı ifade etmektedir (Bakhtin, 2001, s. 316). Filmde de anlatı zamanının öykü mekânıyla birlikte ayrılmaz bir şekilde sunuluşu, bu bağlamda önemli olmaktadır. Bakhtin'e göre kronotop, "zamanla mekân arasında çeşitli toplumsal 
deneyimler aracılığıyla farklı biçimlerde kurulan içsel bağların edebiyattaki özgül görünümlerinin adıdır." Zamanın ete kemiğe bürünmesiyse, kronotop aracılığıyla olur ve mekân, aynı biçimde zaman ve tarih tarafından anlamlandırılmaktadır. Zaman ve mekâna ilişkin deneyimlerin de ham algılardan oluşmaması Bakhtin'in vurguladığı noktalardan biridir (Bakhtin, 2001, s. 28). Bakhtin edebi anlatılarda kullanılan zaman ve mekânla ilgili stratejileri klasik eserler veren yazarların anlatılarından örnekler sunarak anlatmaya çalışmıştır. Gustave Flaubert'in Madam Bovary'sindeki taşra kasabasında zamanın ve mekânın kullanımı, Beş Vakit filmindeki zaman ve mekân kullanımıyla paralellik göstermektedir. Bakhtin, Flaubertçi kategori olarak nitelendirdiği kategorideki döngüsel zaman mahallerinden şöyle söz etmektedir:

\begin{abstract}
Burada hiçbir olaya rastlanmaz, yalnızca kendilerini sürekli yineleyen "etkinlikler" bulunmaktadır. Zaman burada, ilerlemekte olan hiçbir tarihsel devinim barındırmaz; bunun yerine dar devirlerle ilerler, günün, haftanın, ayın, bir kişinin yaşamının devri. Bir gün bir gündür yalnızca bir yıl bir yıldır, bir yaşam bir yaşamdır. Her gün durmadan, aynı etkinlikler döngüsü yinelenir, aynı konuşma konuları, aynı sözcükler vb. (Bakhtin, 2001, s. 321).
\end{abstract}

Beş Vakit'teki karakterler de sürekli kendini yineleyen etkinliklerle zamanın akışı içerisinde yaşarlarken, bir taraftan da tekrar ettikleri hareketlere paralel konuşmalarda bulunmaktadırlar. Bakhtin, açıklamaya çalıştığı zamanın niteliğini, daha da somutlaştırarak tahayyüllerde zamanın algılanmasını kolaylaştırmaktadır ve şöyle devam etmektedir:

Bu zamanın belirtileri basit, işlenmemiş, maddidir; özgül yerlerin, mahallerin gündelik ayrıntılarıyla, kasabanın tuhaf ama hoş küçük evleri ve odalarıla, sessiz sokaklar, toz ve sineklerle, köy kahvesiyle, bilardo salonuyla vb. kaynaşır. Zaman, burada olaydan yoksundur ve bu nedenle, neredeyse havada asılı kalmış gibidir. Hiçbir buluşma, hiçbir ayrılma gerçekleşmez burada. Uzamda kendisini ağır aksak sürükleyen kısır ve kasvetli bir zamandır bu (Bakhtin, 2001, s. 322).

Karakterlerin ebeveynlerine karşı hissettikleri, onların iç çatışmalarıyla izleyiciye sunulurken köyün durağanlığı ön plana çıkmakta, zamanın ve mekânın kendi içlerindeki kısır döngüsü ve aynılığı Bakhtin'in Flaubertci zamansal kategorizasyonuna benzerlik göstermektedir. Bu mekânda gerçekleşen olaylarda da zaman, adeta olaylardan yoksunmuşçasına sunulmaktadır. Sabah, öğlen, akşam, ikindi, gece vakitleri köyde yaşayan insanlar tarafından her gün deneyimledikleri vakitlerin aynılarıdır, yaşadıkları bir gün diğerinin aynısıdır. Karakterlerin hayata dair büyük beklentileri ve umutları yoktur, doğumlar, ölümler ve yaşamın içinde olası olarak karşılaşacakları olaylar, onları beklerken deneyimleyecekleri en büyük hayati olaylar olarak karşılarına çıkmaktadır. Köyde bulunan nesnelerle, karakterlerin yaşantısı birbirinin içine geçerek, zamana eşlik etmektedir. Ahırdaki inekler, yaylalardaki sürüler, ormanlardaki böcekler, vızıldayan sinekler, arılar, çiçeklerin renkliliği, horozların ötüşü kısır döngü zaman içinde yer bularak köye ait demirbaşlar gibi mekâna devinim kazandırmaktadırlar. Anlatı zamanıyla öykü mekânı anlatıda girift bir biçimde bütünleşmektedir. Dolayısıyla izleyici de anla- 
tıda sunulan mekânlar aracılığıyla zamana dair sorgulamalar üretirken zamanın mekânsallaştığını görmektedir. Johannes Fabian, insanlığın mekân içindeki dağılımına özgün anlamlar katanın, doğallaştırılmış-mekânlaştırılmış zaman olduğunu belirtmektedir (Fabian, 1999, s. 77-78). Zamanın ve mekânın anlatıda sentez şekilde algılanması üzerine anlatı stratejilerini inşa eden yönetmen, izleyicinin her iki kavramı hem anlatı içinde hem film zamanı sonrasında bütünlüklü olarak düşünebilecek anlatım dili kullanmaktadır. Gilles Deleuze'ün zaman kristali kavramı, anlatıda zamanın nasıl inşa edildiğine dair çoklu okumalara olanak veren fikirler sunmaktadır. "Zamanın kendini iki benzemez atımda bölmesi, bunların birinin tüm şimdinin geçmesini sağlaması, diğerininse tüm geçmişi saklaması gerekir. Zaman bu bölünmeden ibarettir ve kristalde görülen bu bölünmedir, zamandır" (Zourabichvili, 2011, s. 176). Anlamlandırılması zor olan sanal/gerçek imgelerle, sanal/gerçek sürelerin bir kristalin içinden geçerek ayrışmasını gösteren sinema Deleuze açısından kristal zamanın içeriğini açıklamaktadır (Deleuze, 1997, s. 69). Kristali ışığa tuttuğumuzda, gözümüzle gördüğümüz renk tayfları gibi sinema anlatısı içinde sunulan zaman öğesi de bize zamanın kendi içindeki tayfları hakkında bilgi vermektedir. Beş Vakit, olay örgüsü içinde zamanın inşa edilişi açısından farklı zaman dilimlerini sunduğu gibi, izleyiciler açısından zamanın kristalize oluşuna dair de felsefi sorgulamalar üretmektedir. Anlatı epizotlara ayrılarak sunulsa da çocuk karakterler hayatın içinde deneyimledikleri zamanı istedikleri gibi hissedebilmekte ve heterotopyalarına sığındıklarında kendi kronotoplarını yaratabilmektedirler. Dolayısıyla anlatıdaki zaman kavramının birçok teorisyenin açıklamalarıyla analiz edilişinin temelinde de anlatı zamanının, karakterlerle ve mekânla bağdaşık, felsefi anlamlandırmalara açık sunumu yatmaktadır. Zaman kavramı bu bağlamda hem karakterlerin hem de izleyicilerin zamana dair algısını da detaylandırmakta ve zamana ait kültürel kodların hayatı nasıl şekillendirdiği üzerine de çeşitli okumalar sunmaktadır. Johannes Fabian, antropolog Edward T. Hall'un zamanla ilgili yorumlarını aktarırken zaman kavramında yer alan kültürel kimliğin inşasına değinmektedir: "Zaman konuşur. Sözlerden daha açık konuşur. İlettiği mesaj yüksek sesle ve net olarak ulaşır. Daha az bilinçli olarak manipüle edildiği için, konuşulan dilden daha az çarpıtmaya uğrar ve sözlerin yalan söylediği yerde gerçeği haykırabilir." Fabian, Hall'un zamanı kültürün yapısal bileşenlerinden biri olarak açıkladığını ifade eder. Fabian'a göre de zaman, bir kültürün oluşumuna katkıda bulunur ve zaman kavramları kültürün kimliğini inşa eden inançlar ve değerler sistemine de aitlik göstermektedir (Fabian, 1999, s. 77-78). Bu minvalde, anlatının adı Beş Vakit, Türk kültürü kodlarında yer alan dinsel içeriklerle ilgili zaman kavramına gönderme yapmaktadır denilebilir. Beş vaktin kırsallarda nasıl deneyimlendiği üzerine ve zamanın kristalliğinin kültürel bağlamda yer alışı üzerine sorular üretildiği gibi, kamusal zamanın ve özel zamanın nasıl geçirildiğiyle ilgili sorgulamalar da ortaya çıkmaktadır. Stephen Kern, zamanın sayısı, dokusu ve yönüyle ilgili çelişkili yaklaşımların olduğunu belirtmektedir. Geleneksel tek tip kamusal zamanın gerçekliğine karşı çıkılmazken, özel zamanın çoğulluğunun birçok düşünür tarafından sorgulandığını eklemektedir. Henri Bergson gibi bazı düşünürlerin sabit ve uzamsal olarak ifade edilen kamusal zamanın, zamandan mı yoksa uzam âleminden mi gelen bir metafizik sızıntı olduğu konusunda sorgula- 
malar yaptıklarını vurgulamıştır (Kern, 2013, s. 78). Filmde karakterlerin içinde bulunduğu mekân ve içinde yaşadıkları zaman da bu bağlamda üzerine düşünülebilir sorular ortaya çıkarmaktadır. Çünkü köy, karakterlerin hayatlarını deneyimledikleri mekânları olurken, hayatın akışını yaşadıkları zaman da onların mekânlarına gizlice giren bir sızıntı gibidir. Anlatıda, zaman ve mekân ayrılmaz bütün içinde hareket etmektedir. Anlatı zamanının düz bir çizgi dışında sunumu, öykü mekânının da ekran mekânı ötesinde zihinlerde soyut mekânların izini sürecek mekânların tahayyüllerine izin vermesi, zaman ve mekânın anlatıda temel sinematografik sunumların da ötesinde düşünülerek planlandığını göstermektedir. Zaman dilimleri içindeki anların çocuk karakterler tarafından içkin şekilde deneyimlenmesi, zamanın kristalliğini de ortaya çıkmaktadır. İstedikleri zaman dertlerinden kaçıłları anlar, onların kendileri için zamanı durdukları anlar ve zamanın kolektifliği içindeki tekil zamanının aslında nasıl kristalize olabileceğini gösteren anlardır.

Harvey, Oswald Spengler adlı sosyal bilimcinin, zamana gömülü uzam çokluğunun olduğunu iddia ettiğini söylemiştir. Spengler'a göre, farklı kültürlerin benzersiz uzam ve zaman anlayışları vardır ve bunlar kültürün birincil simgeleri olarak siyasal kurumlarda, dini mitlerde, ahlaki ideallerde, bilim ilkelerinde, resim, müzik ve heykel biçimlerine içkin olarak ortaya çıkmaktadırlar (Kern, 2013, s. 215). Köy, karakterlerin zamana gömülü uzam çokluğu içinde yaşadıkları mekânlarıdır. Ormanlar, ahırlar, evlerinin içi, dağlar, yaylalar mekânların çeşitliliğine işaret ederken, zamanın içine gömülü bir biçimde anlatıda sunulmuştur ve bu anlatım stratejisi de Spengler'ın düşüncelerine benzerlik gösteren zaman ve uzam birlikteliğini hatırlatmaktadır. Kern, Emile Durkheim'ın mantıksal kategorilerin sosyal kategorilerden türediği ve uzamın da bunlardan biri olduğu iddiasını örneklerle sunmaktadır. Durkheim'a göre, uzam iki anlamda heterojendir, toplumdan topluma değişen ve toplum içinde değişikliğe uğrayanlar olarak ayrılmaktadır. Kızılderili Zuniler, uzamı yediye ayırarak kendi kabilelerinden başka mekânın olmadığını, sadece gerçek sınırlarının ötesinde sonsuz oranda genişletildiğini düşünmüşlerdir (Kern, 2013, s. 211). Filmde yaşayanlar da kendi heterotopyaları içinde başka mekânların varlığını hissetmek bir yana, kendi mekânlarıyla bütünleşik biçimde yaşamaktan dolayı bu mekândan dışarı adımlarını atmamaktadırlar. Anlatının baş karakterleri çocuklar olduğu için, karakterlerin yaşadıkları mekândan dışarıya adım atmaya cesaret edememeleri doğal bir durum olarak düşünülebilir. Ancak, yönetmenin anlatıda sunduğu köyde yaşayan yetişkinler de sadece yaşadıkları mekânla sınırlı kalmış ve bu mekân içinde yaşamlarını zamana gömülü biçimde deneyimlemeyi kabul etmişlerdir. Filmin anlatıda odak merkeze aldığı köy mekânı, Durkheim'ın örnek verdiği Zuni kabilesinin yaşadığı uzam gibi, gerçek sınırlarının ötesinde sonsuz oranda genişletilmiş olarak karakterler açısından benimsenmektedir. Dağların yamacından ufka bakan çocuklar hem kendi heterotopyalarının içinden hayatı gözlemlemekte hem de gerçek sınırlarının ötesinde sonsuz oranda genişletilmiş bir mekânın varlığını izleyiciye hissettirmektedirler. Mekânların sunumu, zamanın kristalliğinde var olan renk tayflarındaki sonsuz ışık hüzmesini hatırlatmaktadır. Deleuze, şimdiki/geçmiş, gerçek/hakiki, gerçekliğin ve sanallığın arasındaki 
fark edilmezliğin kesin olarak zihinde üretilmediğini, mutlak var olan imgelerin karakteristiğinin doğasındaki ikilikten kaynaklandığını ifade etmektedir (Deleuze, 1997, s. 69). Deleuze'ün zamana dair söylediği düşünceler paralelinde çocuk karakterlerin sunulduğu öykü mekânlarının içinde var olan ikilikler, yetişkin karakterlerin iç çatışmalarının aynı mekânlardaki sunumunda ortaya çıkmaktadır. Yetişkin erkeklerin babalarına itaat etmeleri, kadın karakterlerin görünür olmaması, patriarkal söylemlerin yaşamlarını yönlendirmesi, erkekliğe ve kadınlığa atfedilen rollerin ataerkil toplumsal düzenin söylemleriyle örtüşmesi, onların yaşadıkları mekânlardaki temsillerini göstermektedir.

Reha Erdem, Beş Vakit filmindeki karakterlerin deneyimledikleri yaşantıları şöyle özetlemektedir: "Tıpkı benim filmlerimde olduğu gibi orada da insanlar zamanın dışında duruyor. Orada farklı bir ritim var. Bizim artık o ritmin içine girmemiz neredeyse imkânsız. Ancak o iklim çok insani. Tam zaman iklimi." (Eşli, 2012, s. 287). Erdem, karakterlerin deneyimledikleri zamanı, zamandışılıkla nitelerken bir taraftan da bizim o ritim içine girmemiz imkânsız diyerek, şehir insanlarının deneyimledikleri ritmin farklı̆ı̆ını hatırlatmakta ve şehir insanın insani olmayan mekânlarda hayatlarını deneyimlediklerini de vurgulamaktadır. Lefebvre ise, zamanın hem yakalanamayan hem de ölçülebilen bir kavram olduğunu hatırlatırken, sayı ve dram olarak yaşama dair bir paradoks olduğunun altını çizmiştir (Lefebvre, 2017, s. 79). Lefebvre, "Bir yer, bir zaman ve bir enerji tüketimi arasında etkileşim olan her yerde ritim vardır" der. Bu ritimler, tekrarlara, doğrusal ve döngüsel süreçlerin müdahalelerine, doğma, büyüme, zirveye ulaşma, gerileme ve sona dayanmaktadır (Lefebvre, 2017, s. 49). Lefebvre, zaman kavramının soyut ve somut olarak algılanabileceği gibi, kendi içinde bir ritiminin de olduğunu söylemektedir. Zamanın ritimlerine izin veren de aralarındaki ilişki biçimleri olagelmektedir (Lefebvre, 2017, s. 32). Ritimleri de kendi içerisinde sınıflandıran Lefebvre, gizli ritim için hem fizyolojik hem de psikolojik ritimlerin içinde bulunduğu (anı, bellek, söylenmiş olan, söylenmemiş olan) ritim olarak nitelendirmektedir (Lefebvre, 2017, s. 43). Ritim analistleri ise, gözlemlenen bedenleri dinleyen, kendi ritimlerini referans alarak birleştiren kişiler olduğunu söyler ve ritimanalistlerin yaşanmış zamansallıktaki bedenleriyle düşündüklerini belirtir (Lefebvre, 2017, s. 46). Lefebvre'nin düşünceleri bağlamında ve Erdem'in anlatıyla ilgili söylemleri düşünüldüğünde, çocuk karakterler, zamandışı gizli ritimleri gözlemleyebilen ritimanalistler gibi ormanların içinde hayatı solumaktadırlar. Lefebvre, ormanların da birden çok biçimde hareket ettiğini söyler; toprağın, yeryüzünün, güneşin birleşik devinimleriyle (Lefebvre, 2017, s. 46). Çocuk karakterlerle birlikte doğanın da kendi içindeki devinimleri hayata dair olan her şeyin, gündelik olanın, ana dair olanın bir bütün halinde onlar tarafından içselleştirildiğini göstermektedir. Lefebvre, gündelik zamanın ritimli örgütlenmesinin en kişisel ve en içsel olduğunu vurgulayarak, herhangi bir ideoloji ve gerçekliğe ait olmadığından bahsetmektedir. Edinilmiş ritimlerin bu örgütlenme içinde hem içsel hem toplumsal oluşu, herkesin aynı anda aynı şeyi yaptığını hatırlatırken bu ritimlerin tekrarlaması sırasında da herkesin aynı anda yalnız olduğu hatırlatılmaktadır (Lefebvre, 2017, s. 102). Şehirli insanlara 
kıyasla yaşamı en içsel ve en kişisel merkezinden hisseden çocuk karakterler de edinilmiş ritimlerle gündelik edimlerini yerine getirirler, ancak onlar yalnızlığı toplumsal yönlendirmelerin etkisiyle seçmezler, kendi içlerindeki gizli ritimlerini duyumsayabilmek adına bunu gerçekleştirmektedirler. Bu minvalde, zamanın ritmini anlamlandırabilmek açısından çocuk karakterler izleyicinin anlatı zamanına dair düşünmesini sağlamaktadırlar.

Paul Ricoeur, zamanın görüsel karakterini Immanuel Kant ve Edmund Husserl'in zamanla ilişkili düşüncelerini açıklayarak yorumlamıştır. Ricoeur'e göre, farklı zamanlar fiilen aynı zamanın parçalarına aittir ve zaman kolektif bir tekillik içermektedir. Zamanı uzayın sonsuz büyüklügüne benzeten Ricoeur, zamanın içsel görümüzün bir biçimi olduğunu ifade ederken özneye içkin bir kavram olduğunun da altını çizmektedir (Ricoeur, 2015, s. 80). Beş vaktin, her gün birbiri ardına aynı edimlerle ve döngülerle tezahür ediyor oluşu, zamanın tekilliği göstermektedir. Bu bağlamda, çocuk karakterlerin yaşamın içindeki zamanla ilişki biçimlerinde zamanın onlar için ne kadar içkin bir kavram olduğu anlatı tarafından düşündürtülürken, anlatıdaki zaman temsilinin çocuk karakterlerle ilişkisi bağlamında da zamanın kolektifliği izleyiciye sunulmaktadır. Çocuk karakterlerin doğayla bütünleşmeleri ve zamanın kolektifliği yanında zamanın sonsuzluğunu sorgulatan sahnelerde doğanın mizansen içinde yer alması anlatının izleyici açııından içselleştirilmesinde önemli rol oynamaktadır. Keza Ricoeur de zaman ve doğa arasındaki ilişkinin ne kadar girift yapıda olduğunu hatırlatmaktadır. "Zamanın, aşkınsal belirlenimleri aracıı̆̆ıyla doğanın sistemini belirlediği söylenebilir. Ancak zaman da doğaya ilişkin aksiyomatiğin inşasıyla belirlenir. Bu anlamda doğa ontolojisinin oluşturucu aksiyomatik sistemi ile zamanın belirlenimlerinin birbirlerini karşııklı olarak belirlediği söylenebilir." (Ricoeur, 2015, s. 89). Zamanı uzayın sonsuz büyüklüğüne benzeten Ricoeur'ün düşüncelerine paralel biçimde Burch da anlatı zamanın içinde var olabilen sınırsız eksiltmeleri vurgulamıştır. Sinematik dilde anlatı zamanı içinde inşa edilen zamana dair sınırsız eksiltmeler, zamanın özneye ne kadar içkin olduğunun ve sonsuz büyüklükte olduğunun felsefi işaretini de sunmaktadır. Öykünün odak merkezinde bulunan zaman kavramı yönetmenin izleyiciyi düşünme süreçleri içerisine soktuğu bir olay örgüsü içinde sunulduğu için, anlatı zamanının içinde zamana dair sınırsızlıkları göstermektedir. Zamandışı̆̆ı̆ anlamlandırılabildiği öykü, karakterlerle olan ilişkisinde kuvvetli bir temsili göstermiştir. Çocuk karakterlerin kendilerine ait kronotoplara sahip oluşları, onların zamanı istedikleri gibi kullanabildiklerini göstermekte ve anlatı zamanının düz bir çizgide ilerlemediğini de temsil etmektedir. Beş Vakit'te sunulan zamandışı ritimle, insani olan iklim içinde hayatı deneyimlemenin olumluluğu üzerine yönetmen izleyiciyi düşündürtebilmektedir. Erdem, kendi ritmimiz dışında gerçekleşen hızlı ritimlerle hayata dair olanı, yaşamın içindeki duyumsanması gereken detayları ve kendi benliğimize dair olanı kaçırdığımız gerçekliğiyle de izleyiciyi yüzleştirmektedir. Bergson, ölçülebilir zaman kavramına karşı çıkarak zamanın somut olmadığını belirtir ve bazı zamanların daha hızlı geçtiği üzerine yorumlar yapmaktadır (Eşli, 2012, s. 47). Erdem'in de belirttiği gibi zamandışılığı yaşayan karakterler adeta Bergson'ın nitelendirdiği ölçülebilir 
zamanın dışında yaşayan kendi zamanlarını yaratan karakterler gibidirler. Her ne kadar film, öykü içinde tek bir günü beş epizota ayırarak anlatı zamanını sunsa da karakterler için günün doğumu, batımı, ezanın sesi, havanın kararması gibi durumlar zamanın ölçülebilirliği dışındaymış gibi yaşanmaktadır. Bergson, Zaman ve Özgür İstenç (1889) adlı eserinde insanların zamanı nasıl yaşadıklarına dair şöyle der:

\begin{abstract}
....Ne var ki, kendi kendimizi ele geçirdiğimiz anlar pek enderdir; işte pek ender özgür olmamızın nedeni de budur zaten. Zamanın çok büyük bölümünde kendi dışımızda yaşarız, kendimize ilişkin kendi hayaletimizden, yani katıksız süresi türdeș uzama yansımıș renksiz bir gölgeden başka hiçbir şey algılamaksızın yaşarız. Öyleyse, yaşamımız zamandan çok uzamda açıp sergiler kendini; kendi kendimizden çok dış dünya için yaşıyoruz demek ki; düşünmek yerine konuşuyoruz öyleyse; kendi kendimiz edimde bulunmak yerine 'edime konu' oluyoruz demek ki. Özgürce eylemek kişinin kendine yeniden sahip çıkması ve katıksız süreye geri dönmesidir (Bergson, 1997, s. 11).
\end{abstract}

Filmin karakterleri, zamanın büyük bölümünü kendi dışlarında yaşarlarken ve gündelik edimlere konu olurken, bir tarafından da özgürce eylemeyi de gerçekleştirmektedirler. Katıksız sürenin içine dâhil olan çocuklar, yetişkinlere oranla daha fazla özgürlüğe sahip olanlar olarak kendi kendilerine vakit yaratanlar ve kendilerini dinleyenlerdir, böylece Bergson'un söylediği gibi ender özgür olanlar, çocuklardır. İstedikleri gibi mekânların içinde konuşmadan duranlar, çimlere yatanlar, ormanın sessizliğini dinleyen karakterler, kendi edimlerini yaratmaktadırlar. Zamanı ve mekânı kendi yaratımlarından ortaya çıkan edimlerle şekillendiren karakterlerin zamanları ve mekânları iç içe geçmekte ve anlatının dramatik kurgusu klasik anlatı yapısının kodlarından farklı biçimde sunulmaktadır. Bu bağlamda Locke'un, "düşüncemizde cisme ve ona ait uzama da sınırlar getirebiliriz, fakat cisim içermeyen uzaya bunu yapamayız, çünkü sayının sınırları nasıl zihnin en geniş kavrama gücünü aşarsa uzay ve süre sınırları da düşüncenin erişilebilirliğinin ötesindedir" düşüncesi anlatıdaki zaman ve mekân öğesinin sunumuyla paralellik göstermektedir (Locke, 2000, s. 257). Karakterlerin doğada geçirdikleri anlar, onları Locke'un da dediği gibi uzay ve süre sınırlarının aşıldığı düşüncenin erişilebilirliğinin ötesine geçirmektedir. Şehir insanına kıyasla doğanın içinde doğal olanla yaşarlar ve bu şekilde hayatı deneyimlerler, Lefebvre'nin gündelik hayatla ilgili düşünceleri bu bağlamda tekrar düşünülebilir hale gelir. Lefebvre, "gündelik hayat mütevazı ve sağlamdır, doğal olandır, kısımları ve parçaları belirli bir zaman kullanımı içinde, kuşkuya meydan vermeyecek bir biçimde birbirlerine bağlanan şeydir" demiştir ve burada gündelik hayatın mütevazılığını vurgulayarak, doğal olanla birlikte ancak sağlam bir yapıya kavuşabileceğini belirtmiştir. Dolayısıyla, köyde her günkü edimlerinin aynısını yaparak hayatını geçiren bireyler, modernizmden uzak biçimde yaşayarak gündelik hayatın mütevazıı̆̆ına ulaşmaktadırlar. "Gündelik hayat, göstergeden ve anlamdan yoksun olan şeylerin toplamı değil midir zaten?" diye soran Lefebvre'e, Beş Vakit'in çocuk karakterleri edimleriyle cevap vermektedirler. Onlar, gösterge ve anlamlar arasında kaybolarak bir şeyleri bulmak yerine, kendi 
mekânları içinde, hayatın anlamını aramaya çalışan karakterlerdir. Z. Tül Akbal Süalp, son dönem Türk Sineması'ndaki taşra güzellemelerinde tepkisel bir zaman ve mekân sorunsalı yaratıldığını belirtmektedir. Böylece, şehirdeki hız ve karmaşadan bunalan ve kendi benliğini de kaybetme eşiğinde olan kahramanların, taşradaki zamanın ağır temposunda ve pastoral manzarasında huzuru aradıklarını söylemiştir (Süalp, 2010, s. 97). Süalp'in düşüncelerinden hareketle, taşranın o pastoral manzarasında ve dingin zaman akışında huzuru bulanlar, film anlatısının baş karakterleri çocuklardır. Taşrada ağır geçen zamanın durağanlığı, geniş planlarla verilmiş pastoral manzaralar, fonda klâsik müziklerle hissedilen sakinlik hissi, hızlı ritimden uzak biçimde hayatı yaşayabilme olanağı şehirde yaşayan izleyici açısından da huzura ulaşabilmenin intimalleri olarak sunulmaktadır. Ancak, şehirli insanın hızlı ritime alışmışlı̆̆ı, taşrada hayatı deneyimlediğinde farklı sonuçlara yol açarken, film anlatılarının izlenme sürecinde başka sonuçlara yol açabilmektedir. Burada ayrılan iki durum, film izleme sürecinde filmsel zaman içindeki süreyle, hayatın kendisinin bizzat birey tarafından yaşantılandığı anın farkııı̆ıdır. Bu bağlamda, yönetmenin, anlatıyı sunmakta kullandığı stratejiler önem kazanmaktadır. Taşranın anlatının odak merkezine alındığı Beş Vakit filmi, şehirde yaşayan bir birey tarafından izlendiğinde, taşraya gitme hayali ya da isteminin izleyicide ortaya çıkmasına imkân verebilir. Yönetmenin sunduğu filmsel zamanının içindeki anlatı zamanının uzun düşünme süreçlerine izleyiciyi ortak edebilmesi, ekran mekânında sunulan görsel etkisi güçlü sahnelerle, öykü mekânının odağında yer alan köy mekânının mekânsal soyutlamalara izin vermesi, tüm bu kavramların sinematografik bağlamda üzerinde düşünülmüş dramatik kurguyla sunuluşu bu hayalin ortaya çıkmasını doğurabilir. Bu minvalde, kronotop ve heterotopyanın anlatıda karakterlerle ilişkisinde güçlü bağlantılııklar bulunmasından dolayı, zaman ve mekân kavramlarının sinematik dilde sunumu öykünün anlamlandırımasında önemli hale gelmiştir.

\section{Sonuç}

Yönetmen, film anlatısını epizotik bir anlatımla beş epizota ayırarak taşrada yaşayan insanların yaşamlarını sunmaya çalışmıştır. Ezan sesi, yeni bir günün başlangıcıyla ilgili bilgi veren en somut vakit göstergesini sunmaktadır. Anlatının odak merkezinde bulunan köy mekânı baş karakterlerin hayatlarını deneyimledikleri mekânları olurken, baş karakterler Yakup, Ömerve Yıldız'ınzamanı deneyimlemeleri de mekânla bütünleşik verilmiştir. Sabah, öğlen, ikindi, akşam, gece vakitleri onlar için başka bir vakte aynı edimlerle geçişi göstermektedir. Okula gidip geldikleri, ebeveynleriyle konuştukları, yemek yedikleri, oyun oynadıkları, düşlere daldıkları anlar vakitlere ayrılmış olsa da onlar için başka bir günün getireceği çok büyük farklıık bulunmamaktadır. Bu bağlamda öykünün odak merkezinde bulunan kavramlardan zaman kavramı, yine öykünün odak merkezinde bulunan öykü mekânıyla girift bir yapı arz etmektedir. Anlatı zamanının epizotlarla ayrımı dahi izleyicinin kendini anlatı zamanını sorgulamasından alıkoymamaktadır. 
Köy, büyükbahçesi olan bir heterotopyayıyaratırken, Yakup, ÖmerveYıldız'ın iç çatışmalarından kaçarken sığındıkları doğa da onlar için kendi heterotopyalarını yarattıkları alanlar haline gelmektedir. Zaman, bir taraftan taşradaki durgunluğun kendi içindeki tekrar döngüsünü vermekteyken, diğer tarafından da çocuklar için akıcılığıyla zamandışı olan bir zaman olarak da nitelenebilinmektedir. Ormanlık alanlarda, dağlık arazilerde yaşamlarını sürdüren, büyük bahçelere sahip olan karakterler, izleyiciyi zaman ve mekânın gündelik yaşam içindeki algısı hakkında düşündürtmektedir. Ancak, Yakup, Ömer ve Yıldız için zaman, yeşillikler içindeki doğanın içinde her zaman, her anı ile akıcılık taşıyamayabilmektedir. Nurdan Gürbilek, şehir insanıyla, taşra insanının sıkıntısını karşılaştıııken, taşrada yaşanan sıkıntının her gün, şehirlilerinse bu sıkıntıyı en çok pazar öğleden sonra yaşayacağı sıkıntı olarak açıklamıştır, çocukluğun kendisinin de bir taşra olduğunu belirten Gürbilek, taşrayı çocukluğa şu şekilde benzetmiştir:

Tıpkı taşra gibi, uzakta yanıp sönen, parlayıp yiten ışığın vaadiyle yaşar çocuk. Her gün onu bekleyen, her sabah onu yanına çağıran bir dünya! Orada, dışarıda, bir anlam vaadi olduğunu fark etmiștir bir kez. Yeni bir oyuncağın uyandırdı̆̆ı umudun yerini birden nasıl koyu bir can sıkıntısına bıraktığını hatırlayan bilir: Çocuğu umutlandıran da, bir şeylerin kendisinden esirgendiğini hissettiren de dışarının vaat ettiği bu anlamdır (Gürbilek, 2016, s. 56).

Film anlatısındaki çocukların yaşadıkları iç çatışmalar ve sıkıntılar da ebeveynlerine karşı hissettikleri duyguların odak merkeze alınışıla sunulmuştur. Bu bağlamda, okulda, ormanlık alanlarda, çimlerin üzerinde, yapraklarla örtündükleri anlarda, zamanın, zamandışıı̆ı ön plana çıkmış olsa da, iç dünyalarında yaşadıkları hüzünler, onları, taşranın hissettirdiği sıkıntıya da zaman zaman sürüklemektedir. Zamanın ne kadar değerli olduğuna dair ve içinde yaşanılan mekânların hayata nasıl yön verdiğine dair yapılabilecek çıkarımlar anlatının sunduklarındandır. Çocuk karakterlerin anlatıdaki mekânları onların heterotopyalarını sunarken, anlatı zamanının çocuk karakterlerle ilişkisi onların zamanla bağdaşıklığını kronotoplaştırmaktadır. Anlatı zamanının, öykü mekânlarına içkinliği çocuk karakterlerin zamanı algılamalarını kronotop bağlamında değerlendirme olanağı sunmakta, izleyicilerin şehir insanının yaşadığı mekânlarını, deneyimledikleri zamanı film zamanı süresince düşündürtebilmektedir. Şehrin kaosu ve hızlı ritimi, şehir insanını kaotik olarak çevrelerken, taşrada yaşayanların dingin tekrarlarla, aynı edimlerde bulunarak hayatı deneyimlemeleri arasındaki büyük farklıık anlatıda sunulmaktadır. Taşrada yaşanan aynı edimler, taşra insanına sıkıntı hissini yoğun hissettirirken, gündelik yaşantıları üzerine de daha detaylı düşünmelerini sağlayabilmektedir. Şehir insanının iş, ev koşuşturması içinde yaşadığı tekrar döngüsü, taşrada yerini doğa ve ev arasında gidip gelen iş döngüsüne bırakmıştır. Taşra insanının durağan hayat ritimi içinde en mükemmel heterotopyadan ufka bakışı, onların büyük bahçeye sahip heterotopyadan başka heterotopyalara da sahip olduklarının göstergesi olmaktadır. Sınırlarından çıkmadıkları, engin maviliklere uçurumdan baktıkları gemileri gibidir köyleri. Yönetmen, köyü anlatının odak merkezine koyarak, hem taşrada yaşanılan hayatın deneyimlemesini mekânsal olarak sunmaktadır, hem de zamanın insanlar tarafından taşrada 
nasıl yaşantılandığına dair sorgulamaları da ortaya çıkarmaktadır. Yakup, Ömer ve Yıldız, yaşadıkları mekânla bağ kuran ve mekânın somut biçimde içine girerek doğayı hisseden karakterler olarak yaşanan mekânlarının filozoflarıdır da. Kendi öznel zamanlarını hissederek yaşayan çocuklar, en mükemmel heterotopya örneğinde dertlerini de paylaşmaktadır. Ailelerine karşı hissettikleri, çatışmaları, hayatın zorlukları onları taşranın durağan ritiminde düşündürücü hale getirmektedir. Karakterler, Kızılderili Zuni kabilesi gibi mekânlarının sonsuz oranda genişletildiğini hissetmektedirler ve izleyici de film anlatısını izleme deneyimi süresince odak merkezde bulunan köyden başka bir mekânın bulunmayışı hissiyatını duyumsamaktadır. Doğal oyunculukların kullanımıyla birleşen doğayla bütünleşmiş köy ve köy yaşantısı, yönetmenin oyuncuları yönetmesindeki başarıyı da göstermektedir. Kendi yarattıkları kronotoplarında düşünen ve mücadele eden Yakup, Ömer ve Yıldız, hayatın zamandışılığının nasıl duyumsanabileceğini de izleyiciye sunmaktadır. Yaşanan mekânları, onların zihinlerinde kurduklarıyla, yaşantıladıklarıyla bütünleşerek, içselleştirdikleri mekânları olagelmiştir. Dağ yamaçlarının ucunda dertlerini paylaştıkları, oyunlar oynadıkları, şiirler okudukları, uçurumun kenarından denizle gökyüzünün birleştiği ufuk çizgisini sessizce izledikleri anlar, onların çocuk dünyalarını izleyiciye sunarken, zamanın ve mekânın algılanmasının çocuklar tarafından daha farklı algılandığını da göstermektedir. Bu bağlamda, çocuk karakterlerle ilişkili sunulan öykü mekânı ve anlatı zamanı izleyicinin de öykü mekânını ve anlatı zamanını çocuk karakterlerin perspektifinden anlamlandırmasını sağlarken yetişkin izleyicinin hayatlarına dair yaşadıkları zamanın ve mekânın özünü de tekrar düşünebilmelerinin önünü açmış ve üçüncü mekânlar gibi alternatif mekânların da yaratılabilme olasıı̆ğını ortaya koymuştur.

Geniş planlarla çekilen ormanlık alandaki sahneler, çocukların doğayla bütünleştiği ve doğanın parçalarıyla bedenlerini bir araya getirdikleri kısa sekanslarla yapılan geçişler, anlatının dramatik kurgusuna şiirsellik katarken, fonda duyulan klasik müziğin dinginliğiyle izleyici pastoral görsellikle, anlatıdaki zaman ve mekânın algııını daha da içselleştirebilmektedir. Erdem, Beş Vakit’le Türk Sineması'nda zaman ve mekânın film anlatısında sunumu açısından katkı sağlamış ve yeni anlatı stratejilerinin geliştirilmesinde de ufuk açıcı bir bakış açısı sergilemiştir.

\section{Kaynakça}

Bakhtin, M. (2001). Karnavaldan Romana: Edebiyat Teorisinden Dil Felsefesine Seçme Yazılar. (C. Soydemir, Çev.). İstanbul: Ayrıntı Yayınları.

Bal, M. (1999). Narratology Introduction to the Theory of Narrative (Second Edition). Toronto: University of Toronto Press.

Bhabha K. H. (2016). The Commitment to Theory, S. 5. Erişim 1 Mart 2016, http://banmarchive.org.uk/collections/newformations/05_05.pdf

Bergson, H. (1997). Zaman ve Özgür İstenç. (A. Tümertekin, Çev.). Cogito Dergisi, $11,7-15$. 
Bordwell, D. (2017). Three Dimensons of Film Narrative, Erişim 2 Aralık 2016, http://www.davidbordwell.net/books/poetics_03narrative.pdf

Bordwell, D. (2017). Camera Movement and Cinematic Space, Cıné - Tracts: A Journal of Film, Communications. Culture, and Politics. (D. Allen, T. De Lauretis, Çev.). Erişim 6 Ekim 2017, https://library.brown.edu/cds/cinetracts/CT02.pdf

Bordwell, D., Thompson, K. (2012). Film Sanatı: Bir Giriş. (E. Yılmaz, E. S. Onat, Çev.). Ankara: Deki Yayınları.

Bordwell, D. (1985). Narration in the Fiction Film. United States of America: University of Wisconsin Press.

Borges, L. J. (2015). Ficciones: Hayaller ve Hikâyeler. (F. Özgüven, T. Uyar, Çev.). İstanbul: Illetişim Yayınları.

Burch, N. (1981). Theory of Film Practice. (H. R. Lane, Çev.). Princeton, New Jersey: Princeton University Press.

Chatman, S. (2009). Öykü ve Söylem: Filmde ve Kurmacada Anlatı Yapısı. (Ö. Yaren, Çev.). Ankara: Deki Yayınları.

Cutting, E. J., Iricinschi C., Brunick L. K. (2013). Mapping Narrative Space in Hollywood Film. Erişim 5.01.2018, https://pdfs.semanticscholar. org/013f/847298891d58a2f4604ec53d9f1bd6b65d5b.pdf

Deleuze, G. (1997). Cinema 2 The Time-Image. (H. Tomlinson, R. Galeta, Çev.). Minneapolis: University of Minnesota Press.

Dökmeci, i. ve Dökmeci, H. (2005). Türkçe Okunuşlu Yeni Tıp Sözlüğü. Nobel Yayınları: Istanbul.

Eşli, Ö. M. (2012). Türk Sinemasının Felsefi Arka Planı: Sinemayı Felsefeyle Düşünmek. İstanbul: Doruk Yayınları.

Fabian, J. (1999). Zaman ve Öteki: Antropoloji Nesnesini Nasıl Kurar?. (S. Budak, Çev.). Ankara: Bilim ve Sanat Yayınları.

Foucault, M. (2017). Öteki Mekânlara Dair, (B. Boysan, D. Erksan, Çev.). Erişim 4 Kasım 2016, https://www.academia.edu/31432896/\%C3\%96teki_mekanlara_ dair

Gürbilek, N. (2016). Yer Değiştiren Gölge Denemeler. İstanbul: Metis Yayınları.

Harvey, D. (2011). Umut Mekânları. (Z. Gambetti, Çev.). İstanbul: Metis Yayınları. Johnson, P. (2006). Unravelling Foucault's Different Spaces. History of The Human Sciences. 19, 14, 75-90, England: Sage Publications.

Heath, S. (2017). Narrative Space. Erişim 08.01.2018, http://staff.washington. edu/cbehler/teaching/coursenotes/Heathnarrsp.html

Kern, S. (2013). Zaman ve Uzam Kültürü (1880-1918). (A. Selman, Çev.). İstanbul: İletişim Yayınları. 
Lefevbre, H. (2014). Mekânın Üretimi. (I. Ergüden, Çev.). İstanbul: Varlık Yayınları. Lefevbre, H. (2007). Modern Dünyada Gündelik Hayat. (I. Gürbüz, Çev.). İstanbul: Metis Yayınları.

Lefevbre, H. (2017). Ritimanaliz: Mekân, Zaman ve Gündelik Hayat. (A. L. Batur). İstanbul: Sel Yayıncılık.

Locke, J. (2000). İnsanın Anlama Yetisi Üzerine Bir Deneme. (M. D. Topçu, Çev.). Ankara: Öteki Yayınları.

Özdemir, B. G. (2016). Filmler İçin Denemeler (Yayımlanmamış Deneme). İstanbul.

Ricoueur, P. (2015). Zaman ve Anlatı 4: Anlatılan (Öykülenen) Zaman. (U. Öksüzan, A. Altınörs Çev.). İstanbul: Yapı Kredi Yayınları.

Soja, E. (1996). Thirdspace: Journey to Los Angeles and Other Real and Imagined Places. Cambridge, Mass.: Blackwell.

Süalp, A. T. Z. (2010). Taşrada Saklı Zaman-Geri Dönülmeyen. Z. T. A. Süalp, A. Güneş, (Ed.), Taşrada Var Bir Zaman içinde (87-116). İstanbul: Çitlembik Yayınları.

Topinka, J. R. (2010). Foucault, Borges, Heterotopia: Producing Knowledge in Other Spaces. Foucault Studies, 9, 54-70.

Urbach, H. (1998). Writing Architectural Heterotopia. The Journal of Architecture, 3:4, 347-354.

Urry, J. (2015). Mekânları Tüketmek. (R. Öğdül, Çev.). İstanbul: Ayrıntı Yayınları. Yücel, F. (2009). Reha Erdem Sineması: Aşk ve Isyan. İstanbul: Çitlembik Yayınları.

Zourabichvili, F. (2011). Deleuze Sözlüğü. (A. U. Kılıç, Çev.). İstanbul: Say Yayınları. 